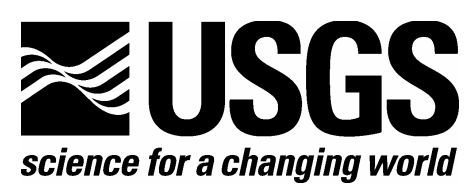

\title{
Vegetation Response to the 1995 Drawdown of the Navigation Pool at Felsenthal National Wildlife Refuge, Crossett, Arkansas
}

By Rebecca J. Howard and Christopher J. Wells

Open-File Report 2007-1379

U.S. Department of the Interior

U.S. Geological Survey 


\section{U.S. Department of the Interior DIRK KEMPTHORNE, Secretary \\ U.S. Geological Survey \\ Mark D. Myers, Director}

U.S. Geological Survey, Reston, Virginia 2007

For product and ordering information:

World Wide Web: http://www.usgs.gov/pubprod

Telephone: 1-888-ASK-USGS

For more information on the USGS - the Federal source for science about the Earth, its natural and living resources, natural hazards, and the environment:

World Wide Web: http://www.usgs.gov

Telephone: 1-888-ASK-USGS

Suggested citation:

Howard, R.J., and Wells, C.J., 2007, Vegetation response to the 1995 drawdown of the navigation pool at Felsenthal National Wildife Refuge, Crossett, Arkansas: U.S. Geological Survey Open-File Report 2007-1379, 52 p.

Any use of trade, product, or firm names is for descriptive purposes only and does not imply endorsement by the U.S. Government.

Although this report is in the public domain, permission must be secured from the individual copyright owners to reproduce any copyrighted material contained within this report. 


\section{Contents}

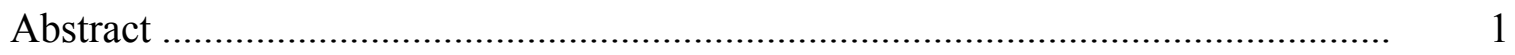

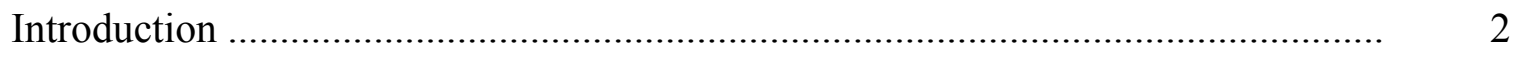

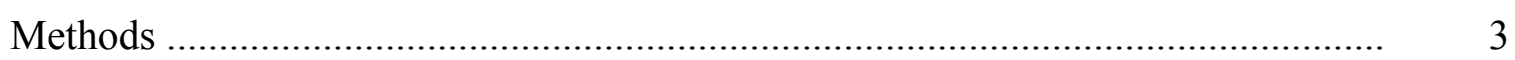

Study Area and Experimental Design ………………................................. 3

Data Collection ....................................................................................

Statistical Analysis ...............................................................................

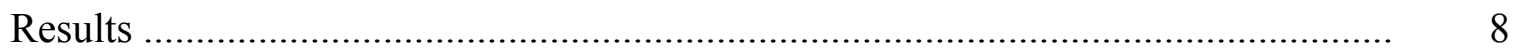

Transects and Plant Community Descriptions …………………………........ 8

Transect and Elevation Effects ............................................................... 19

Disturbance and Elevation Effects ................................................................ 23

Base Pool Stage Vegetation ........................................................................ 29

Seed Bank ........................................................................................ $\quad 30$

Soil Characteristics ...................................................................................... 33

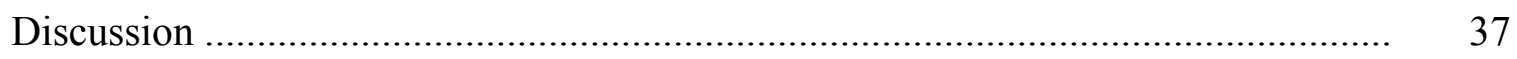

Conclusions and Management Implications ............................................................ 41

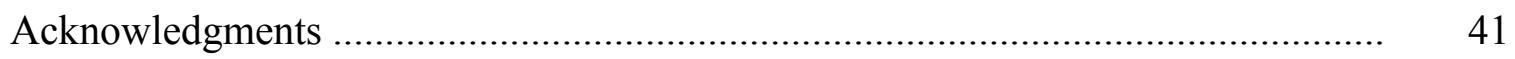

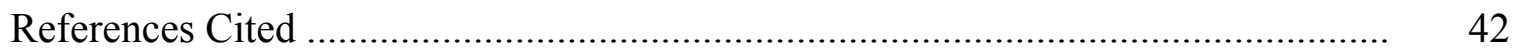

Appendix 1. Description of 19 transects monitored at Felsenthal National Wildlife Refuge from June 1995 to June 1996, indicating quadrat distance from base

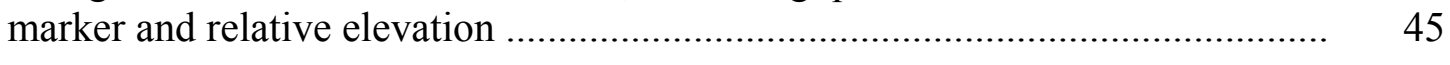

Appendix 2. Plant species percentage of frequency of occurrence at five sampling times at Felsenthal National Wildlife Refuge .......................................................

Appendix 3. Plant species total cover summed over transects at five sampling times at Felsenthal National Wildlife Refuge 


\section{Figures}

1. Mean daily water levels recorded at Felsenthal lock and dam ............................. 4

2. Map of Felsenthal National Wildlife Refuge showing approximate locations of transects ..................................................................................

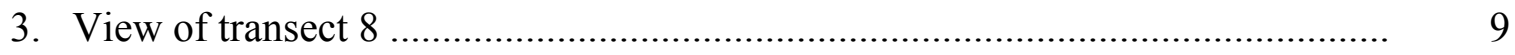

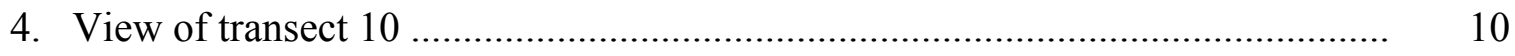

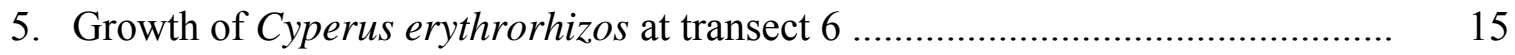

6. Total species richness by transect ............................................................... 16

7. Total vegetation cover by transect ………………......................................... 17

8. Total Cyperus cover (includes C. erythrorhizos, C. iria, and Cyperaceae)

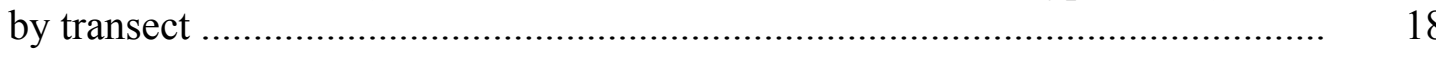

9. Duncan's multiple range test from an ANOVA of the effect of transects on vegetation response ......................................................................................

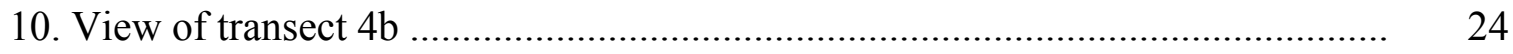

11. Species richness by elevation class on undisturbed and disturbed transects ....... 26

12. Total vegetation cover by elevation class on undisturbed and disturbed transects

13. Cyperus cover by elevation class on undisturbed and disturbed transects .......... 28 


\section{Tables}

1. Modified Daubenmire cover scale used to estimate species cover ........................ 6

2. Location and description of permanent vegetation transects ............................... 11

3. Plant species identified at 19 transects at Felsenthal Navigation Pool, Felsenthal National Wildlife Refuge

4. Five most frequently-occurring species and five species with the highest total cover at five sampling times

5. Overall vegetation response at five sampling times on undisturbed transects and four sampling times on disturbed transects

6. Results of an ANOVA of undisturbed and disturbed transects during base pool water stage

7. Results of repeated measures MANOVA of undisturbed and disturbed transects during pool drawdown

8. Results of a repeated measures ANOVA of elevation effects on vegetation at undisturbed transects

9. Results of a paired t-test analysis of disturbance effect on vegetation during pool drawdown at five paired transects

10. Vegetation response at five undisturbed and five disturbed transects

11 Count of species present in 20 or more quadrats summed across all undisturbed transects in June 1995 or June 1996, plus the introduced species Bacopa egensis

12. Total cover at transects in June 1995 and June 1996 of species with cover that exceeded 400 percent summed across all transects at either time, plus the introduced species Bacopa egensis

13. Species that germinated in soil collected at Felsenthal National Wildlife Refuge in June and October 1995, and the presence of those species in the standing vegetation during field sampling

14. The ten most-frequently germinating species in soil samples collected in June and October 1995 at Felsenthal National Wildlife Refuge 
15. Species richness of seed bank samples and of standing vegetation in high and low elevation quadrats

16. Soil characteristics at 14 transect locations at Felsenthal National Wildlife

Refuge, June 2005

17. Concentration of eight essential plant nutrients in soil collected in June 1995 at 14 transects at Felsenthal National Wildlife Refuge

18. Results of an ANOVA of the effects of transect and elevation on the content of eight plant nutrients in soil at Felsenthal National Wildlife Refuge

19. Representation of Duncan's multiple range test means comparisons by nutrient from an ANOVA of transect effect on soil nutrient concentration at Felsenthal National Wildife Refuge in June 1995

20. Precipitation by month in 1995 and 30 year (1961-1990) mean monthly precipitation in Crossett, Ark.

\section{Conversion Factors}

SI to Inch/Pound

\begin{tabular}{lll}
\hline \multicolumn{1}{c}{ Multiply } & By & To obtain \\
\hline Length & & \\
\hline centimeter (cm) & 0.3937 & inch (in.) \\
millimeter (mm) & 0.03937 & inch (in.) \\
meter (m) & 3.281 & foot (ft) \\
kilometer (km) & 0.6214 & mile (mi) \\
\hline Area & & \\
\hline hectare (ha) & 2.471 & acre \\
\hline
\end{tabular}

Horizontal coordinate information is referenced to the North American Datum of 1983 (NAD 83) 


\title{
Vegetation Response to the 1995 Drawdown of the Navigation Pool at Felsenthal National Wildlife Refuge, Crossett, Arkansas
}

\author{
By Rebecca J. Howard and Christopher J. Wells
}

\begin{abstract}
Felsenthal Navigation Pool ("the pool") at Felsenthal National Wildlife Refuge near Crossett, Ark., was continuously flooded to a baseline elevation of $19.8 \mathrm{~m}(65.0 \mathrm{ft})$ mean sea level (m.s.1.) from late fall 1985, when the final in a series of locks and dams was constructed, until the summer of 1995. Water level within the pool was reduced by $0.3 \mathrm{~m}(1.0 \mathrm{ft})$ beginning July 5 , 1995, exposing about 1,591 ha (3,931 acres) of sediment; the reduced water level was maintained until October 25 of that year. A total of 15 transects was established along the pool margin before the drawdown, extending perpendicular from the pool edge to $19.5 \mathrm{~m}(64.0 \mathrm{ft})$ in elevation. Plant species composition and cover were recorded at six to seven quadrats on each transect; 14 of the transects were also monitored three times during the drawdown and in June 1996. Soil near five of the original transects was disturbed two weeks into the drawdown by scraping the soil surface with a bulldozer. Soil cores were collected to characterize soil organic matter, texture class, carbon and nitrogen content, and plant nutrient concentrations; soil samples were also collected to identify species present in the seed bank prior to and during the drawdown.

Plant species, several of which were high quality food sources for waterfowl, colonized the drawdown zone within four weeks. Vegetation response, measured by species richness, total cover, and cover of Cyperus species, was often greater at low compared to high elevations in the drawdown zone; this effect was probably intensified by low rainfall during the summer of 1995. Vegetation response on the disturbed transects was reduced compared to that on the undisturbed transects. This effect was attributed to two factors: (1) removal of the existing seed bank by the disturbance technique applied and (2) reduced incorporation of seeds recruited during the drawdown because of unusually low summer rainfall. Seed bank studies demonstrated that several species persisted despite nearly 10 years of continual flooding, and that seed bank species richness increased during the drawdown. Analyses indicated that predominantly clay soils containing relatively low organic matter were present along the pool margin. Levels of the plant nutrients measured were consistent with normal values reported for soils. Although conclusions from this study are limited by its one-year time frame, it is unlikely that permanent change to plant community function in the drawdown zone resulted from the lowered water levels during the summer of 1995. While species composition in the summer following the drawdown differed from that prior to the drawdown, the plant community remained dominated by annual floating-leaved or submersed species. It is probable that any future decrease in summer water levels in the pool will result in increased growth of desirable waterfowl food plants, such as Cyperus erythrorhizos (red-root flat sedge) and Leptochloa fascicularis var. fascicularis (bearded sprangletop), in the drawdown zone.
\end{abstract}




\section{Introduction}

Felsenthal National Wildife Refuge (NWR), near Crossett, Ark., was established with a primary objective of providing high quality habitat for wintering and resident waterfowl species. Effective waterfowl habitat management requires ensuring that adequate food is present, including both macroinvertebrate (for example, insects, mollusks, isopods) and plant food sources. Plant food quality and quantity are influenced by seed bank composition, plant germination conditions, and plant growth and survival. Land managers within the lower Mississippi River Valley ecosystem use various methods to influence plant succession and composition in wetlands with the intent to increase habitat quality for various invertebrate and vertebrate species; methods include water level manipulation, prescribed fire, soil treatments such as disking, and vegetation plantings. These actions demonstrate recognition of the importance of disturbance regimes in affecting wetland plant community structure and function and in influencing biodiversity in wetland systems. Two management techniques widely used by land managers to improve wetland habitat quality for waterfowl include constructing greentree reservoirs in forested areas to manipulate water levels and seasonally flooding herbaceous habitats, a practice called moist-soil management.

Greentree reservoirs (GTRs) are created by impounding bottomland forest habitat during the dormant season to increase food availability for migrating and wintering waterfowl (Fredrickson and Batema, 1992). Early reports on the effects of GTRs indicated either no impacts or positive impacts of the flooding regime on tree health and mast production (Broadfoot, 1958; Merz and Brakhage, 1964; Broadfoot, 1967). Later studies, however, demonstrated long-term negative impacts of GTR management on forest composition and structure (Malecki and others, 1983; Wigley and Filer, 1989; Young and others, 1995; King and Allen, 1996; King and others, 1998; Fredrickson, 2005; Gray and Kaminski, 2005; Ervin and others, 2006), including a shift to more flood-tolerant species and reduced woody species regeneration. Moist-soil management practices involve manipulating water depth within impoundments to stimulate growth of herbaceous plants from seeds or tubers present in the soil, thereby maximizing food production (Reineke and others, 1989). Several factors may influence the resulting vegetation community on moist-soil management units, including timing of the drawdown, seed or propagule availability, soil type, soil temperature, soil salinity, litter, and soil moisture level (Fredrickson, 1991; Brock and others, 1994). Direct soil manipulation such as disking and tilling have also been used in moist-soil management to influence plant community composition and structure (Fredrickson and Taylor, 1982; Fredrickson and Reid, 1988; Gray and others, 1999). Nevertheless, a host of abiotic and biotic factors that affect seed germination and propagule success make it difficult to predict the outcome of moist-soil management practices. The correlation between composition of seed banks and standing vegetation often varies among sites within a wetland (Leck, 1989; Rossell and Wells, 1999) and over time (Leck and Simpson, 1995). Predictions may be further complicated by hydrologic history that can also influence the composition of the seed bank and seed viability. Species richness (number of species) of freshwater marsh seed banks was found to decrease with increasing water depth (Wilson and others, 1993). Few viable seeds of emergent plants were found in sediments from a Texas reservoir following several years of inundation (van der Valk and Pederson, 1989). Schneider and Sharitz (1986) also noted that continuous flooding decreased incorporation of tree seeds in forested wetland seed banks. 
Management actions in 1995 at Felsenthal NWR included an experimental drawdown of a large reservoir associated with the refuge GTR. This action represented implementation of moist-soil management practices. Several agencies were involved in assessing drawdown effects on navigation, habitat, water quality, recreation, cultural resources, and fish and wildlife resources. The objectives of this study were to (1) describe vegetation succession and soil characteristics within the zone exposed by the reduced water level, (2) determine the influence of soil elevation on plant species composition, (3) compare postdrawdown vegetation to the species composition of the available seed bank, and (4) quantify the effect of soil disturbance on plant community composition and structure.

\section{Methods}

Study Area and Experimental Design

Felsenthal NWR was established in 1975 to partially mitigate impacts of the U.S. Army Corps of Engineers' (USACE) Ouachita-Black Rivers Navigation Project on bottomland forest habitat. The navigation project included construction of Felsenthal lock and dam in 1985, which, in combination with an earlier-constructed dam, resulted in flooding of refuge lands below $19.8 \mathrm{~m}(65.0 \mathrm{ft}) \mathrm{m} . \mathrm{s} .1$. Approximately 6,450 ha $(15,938$ acres $)$ of bottomland forest habitat were permanently flooded by the resulting reservoir (King and others, 1998). The reservoir, Felsenthal Navigation Pool (hereafter referred to as "the pool"), is managed by the USACE Vicksburg District. Under the routine GTR management schedule, pool water level is held at $19.8 \mathrm{~m}$ through the spring, summer, and early fall each year. In early November, the water level is gradually raised to a maximum of $21.3 \mathrm{~m}(70.0 \mathrm{ft})$, held at this level for a few weeks, and then gradually lowered to reach base pool level in early March. As noted by King and others (1998), however, this schedule has been altered to allow extended flooding into spring during some years, and heavy rainfall events have prevented lowering water levels during other years. Under the GTR management schedule, the pool was continuously flooded to at least 19.8 $m$ from November 1985 until the summer of 1995 (fig. 1). On July 5, 1995, the USACE initiated a partial drawdown of the pool to reduce the water level by $0.3 \mathrm{~m}(1.0 \mathrm{ft})$. The target drawdown level was realized on July 15, 1995, and exposed about 1,591 ha (3,931 acres) of previously flooded soil (geographic information system [GIS] analysis conducted by the U.S. Geological Survey National Wetlands Research Center, Lafayette, La.). Water levels in the pool were raised beginning October 25, 1995, and the base water level of $19.8 \mathrm{~m}$ was reached on November 5; the pool was retained at this level until December 1, when water was gradually raised to reach a winter water level of $21.0 \mathrm{~m}(69.0 \mathrm{ft})$ in the GTR by January 1, 1996 (Felsenthal NWR Annual Narrative Report - Calendar Year 1995). 


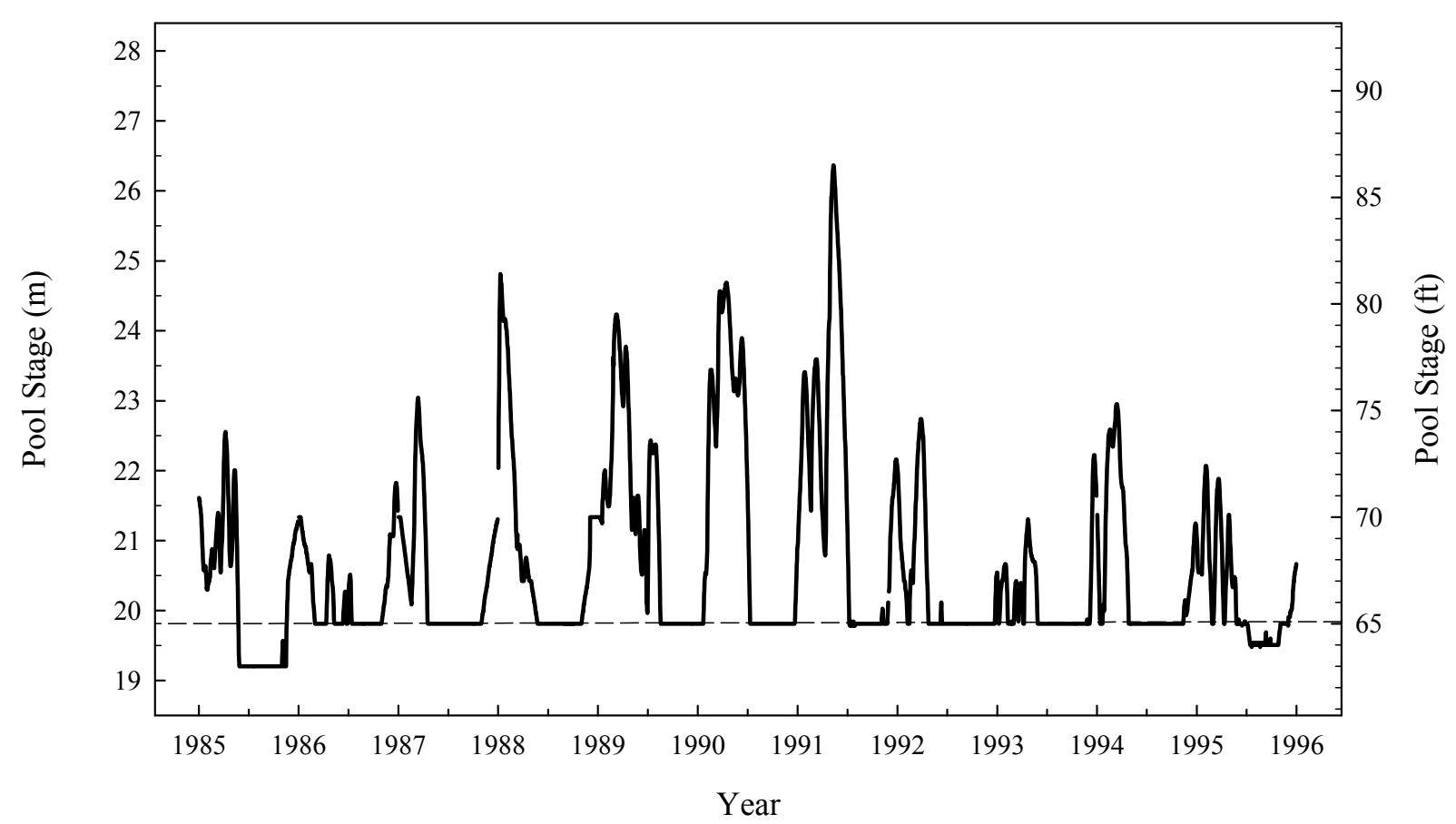

Figure 1. Mean daily water levels recorded at Felsenthal lock and dam from 1985 to 1996. Major tic marks on the $\mathrm{x}$ axis indicate January 1, and minor tic marks indicate July 1 of each year.

Plant community composition and structure as well as environmental characteristics were monitored prior to the drawdown along 15 permanent transects (fig. 2) that were selected by refuge staff as characteristic of the pool margin. The base of each transect was located at the pool edge prior to the drawdown event (reference elevation $19.8 \mathrm{~m}$ ), and transects extended perpendicular from the pool margin into the pool to end at $19.5 \mathrm{~m}(64.0 \mathrm{ft})$ in elevation. Global Positioning System (GPS) locations (NAD83) were determined for the transect bases; the readings were corrected by using real-time differential with the Vicksburg, Miss., broadcast site and were accurate within 1-5 $\mathrm{m}$. Permanent 1- $\mathrm{m}^{2}$ sampling quadrats were located at the pool margin (base station or quadrat 0 ) for each transect and at decreasing elevation intervals of approximately $6.1 \mathrm{~cm}(0.2 \mathrm{ft})$. Elevation at each quadrat was measured with a laser level. Six quadrats, with the final quadrat located at about $19.5 \mathrm{~m}$ elevation, were initially established for each transect. The lower left corner of each quadrat was marked with a pin-flag, and the horizontal distance between quadrats was recorded. Quadrat elevation was measured again following drawdown; there was a liquid soil slurry at the sediment surface that consolidated upon drying, and postdrawdown elevations were often higher than those obtained prior to drawdown (that is, the soil slurry did not support the weight of the survey rod). For several transects, a seventh quadrat was added to sample the true lower extent of the drawdown. Considering the original pool edge as a reference elevation level of $30.5 \mathrm{~cm}(1.0 \mathrm{ft})$, postdrawdown quadrat elevations were classified into two categories: high $(\geq 15.0 \mathrm{~cm}[0.5 \mathrm{ft}])$ and low $(<15.0 \mathrm{~cm})$. 


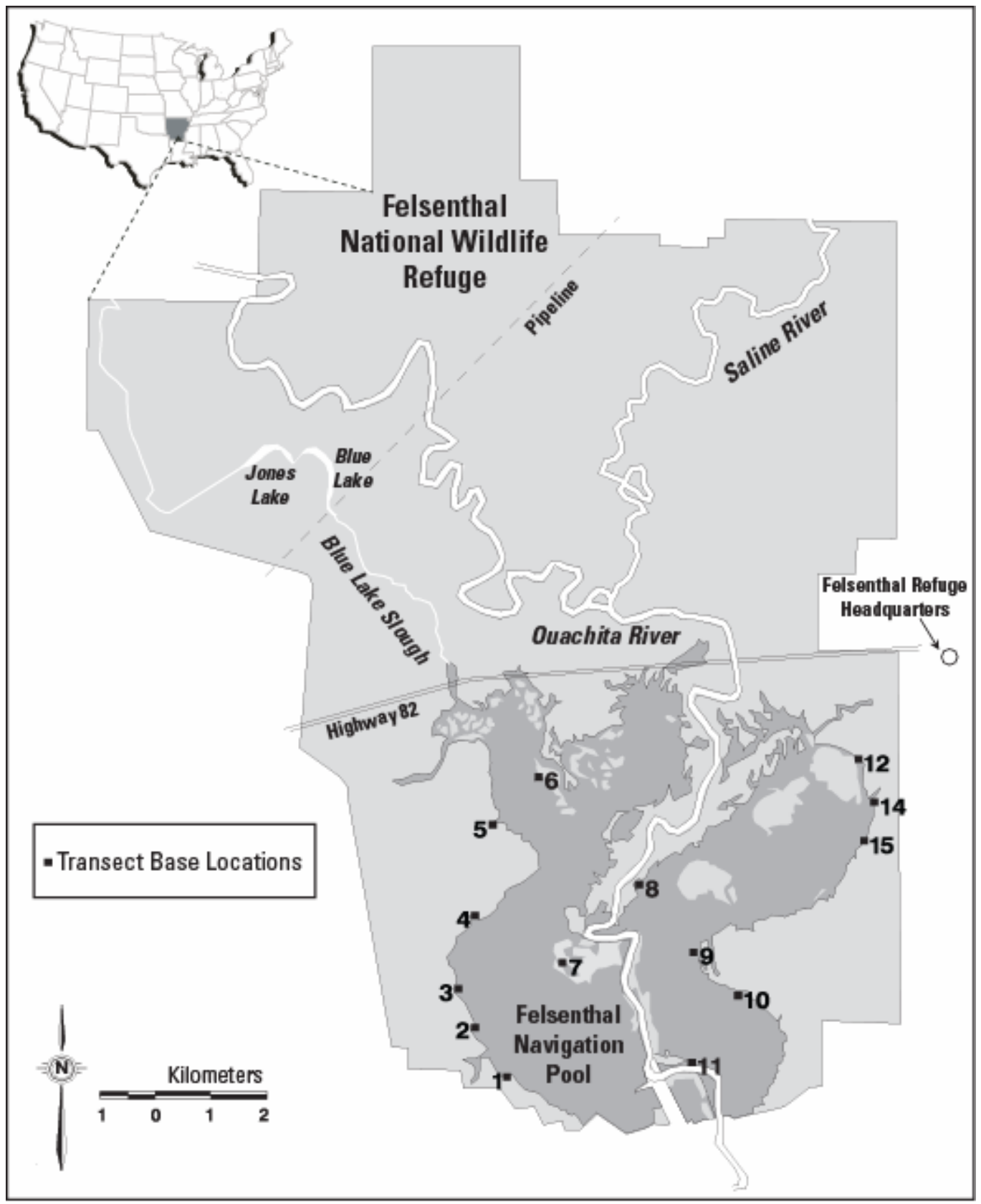

Figure 2. Map of Felsenthal National Wildlife Refuge showing approximate locations of transects along the perimeter of Felsenthal Navigation Pool. Transect 13 was dropped from the study after initial measurements in June 1995 . 
Two weeks following the drawdown, soil disturbance treatments were established for five transects that were accessible to heavy equipment. The disturbance consisted of scraping the soil surface with a bulldozer to create a strip about 10-m wide parallel to, and about $20 \mathrm{~m}$ to the right of, the original transect. The five paired transects were identified by following the transect number designation with the letter "a" for undisturbed transects and the letter "b" for disturbed transects. Vegetation at one of the original transects (transect 13) was heavily impacted by rice (Oryza sativa) planting and the construction of a waterfowl trapping station immediately following the drawdown and consequently was dropped from the study. As a result, 19 transects were monitored following the drawdown.

\section{Data Collection}

A vegetation survey was conducted on the original 15 transects prior to the initiation of the pool drawdown, beginning June 26, 1995. Species composition was recorded, and cover class of all species was estimated in each quadrat by using a modified Daubenmire cover scale (Bonham, 1989) (table 1). Cover classes for exposed soil, standing water, and dead vegetation were also recorded. In June 1995, a soil core (9-cm diameter by $15-\mathrm{cm}$ deep) was collected outside each quadrat to determine soil organic matter, and carbon and nitrogen content. This core was also used to measure the concentration of the plant nutrients $\mathrm{Cu}, \mathrm{Zn}, \mathrm{Mn}, \mathrm{Fe}, \mathrm{P}, \mathrm{Mg}, \mathrm{Ca}$, and $\mathrm{K}$ (listed in order of increasing concentration required by plants for growth and metabolism). An additional core was collected outside quadrat 1 (high elevation, about $24 \mathrm{~cm}$ ) and quadrat 4 (low elevation, about $6 \mathrm{~cm}$ ) at each transect for seed bank analysis. A final soil core was collected midtransect, outside quadrat 2 (about $18 \mathrm{~cm}$ elevation), for analysis of particle size distribution of the soil mineral fraction (that is, sand, silt and clay content). All soil samples were stored on ice in the field and refrigerated upon return to the laboratory until analysis. No initial data were collected for the areas designated as soil disturbance treatments.

Table 1. Modified Daubenmire cover scale used to estimate species cover. Classes may sum to greater than 100 percent cover because different height strata may overlap.

\begin{tabular}{ccc}
\hline Cover Class & Percent Cover & $\begin{array}{c}\text { Class Midpoint } \\
\text { Percent }\end{array}$ \\
\hline P & $<1$ & 0.5 \\
1 & $1-10$ & 4.5 \\
2 & $11-25$ & 18 \\
3 & $26-50$ & 38 \\
4 & $51-75$ & 63 \\
5 & $>75$ & 88 \\
\hline
\end{tabular}


Subsequent to pool drawdown, transects with soil disturbance were established near five of the original transects and all 19 transects were sampled at approximately 6-week intervals beginning August 1 (time 2), September 12 (time 3), and October 23 (time 4). Plant species composition and cover were measured during all sampling events. In October, soil core samples were collected outside quadrat 0 (30.5 cm elevation) and quadrat 5 (about $0 \mathrm{~cm}$ elevation) for seed bank analysis, and outside quadrat 4 (about $6 \mathrm{~cm}$ elevation) for determination of organic matter and carbon and nitrogen content. The soil core used for sample collection was $2 \mathrm{~cm}$ in diameter and $15 \mathrm{~cm}$ deep; to compensate for the smaller sample size compared to the June soil samples, three cores were taken at each location and combined prior to analyses. Species composition and cover were sampled a final time in June 1996 (time 5) at base pool water level.

Species composition of the seed bank was determined by using the seedling emergence method (Poiani and Johnson, 1988). Soil cores were stored about 3 months at $7{ }^{\circ} \mathrm{C}$; following cold storage, the samples were mixed with tap water, and large plant tissues were removed to prevent regeneration from remnant rhizomes. The resulting slurry was evenly spread over potting soil in standard plastic flats $(25.4-\mathrm{cm}$ by $25.4-\mathrm{cm}$ by $5.1-\mathrm{cm}$ deep). The flats were randomly arranged in a greenhouse in Lafayette, La. on a plastic-lined table, and water on the table was maintained at a constant depth of $2 \mathrm{~cm}$ by adding tap water. A water-cooling system in the greenhouse kept the maximum temperature below $35^{\circ} \mathrm{C}$. Cover class of all seedlings was estimated after 6 weeks; all seedlings were then removed from the trays. Cover was estimated a second time after an additional 8 weeks of growth. The two seed bank experiments were initiated on September 22, 1995 (June samples) and April 8, 1996 (October samples).

Soil cores for physical and chemical analyses were dried at $55^{\circ} \mathrm{C}$ to a constant weight. The dried samples from all quadrats were homogenized by mixing and then were divided into two subsamples. Organic matter of one subsample was determined by applying loss upon ignition techniques (Soil and Plant Analysis Council, 1992). The second soil subsample was sieved through a 2-mm mesh screen and then further divided into two subsamples. Total soil nitrogen and carbon content was obtained for one subsample by using a CE 440 Elemental Analyzer (Leeman Labs, Inc., Lowell, Mass.). Micronutrients were extracted from the second by using nitric acid and microwave digestion (Nieuwenhuize and others, 1991), and nutrient concentrations in the extractions were evaluated with an inductively-coupled argon plasma spectrometer (ICP) (Optima 3000, PerkinElmer, Inc., Waltham, Mass.). Organic matter in the samples collected for particle size distribution was removed by digestion in household bleach. The sand fraction was then separated with wet sieving, and the remaining clay and silt fractions were determined by using the pipette method (Schumacher and others, 1995).

\section{Statistical Analysis}

All analyses were conducted by using SAS/STAT ${ }^{\circledR}$ software, Version 6 (SAS Institute, Inc., Cary, N.C.). A multivariate two-way nested analysis of variance (ANOVA) model was used to analyze vegetation prior to (June 1995, time 1) and following (June 1996, time 5) the drawdown, with transect and elevation class (low or high) within transect as independent variables. The analyses were conducted by using the general linear model procedure (Proc GLM) of SAS software. A significance level of $\alpha=0.05$ was used for these and all subsequent analyses; the significance level was adjusted for the number of comparisons when appropriate. When required, appropriate variable transformations were made to conform to model assumptions. To 
determine how vegetation responded during the drawdown (times 2-4), a repeated-measure multivariate ANOVA (MANOVA) model was applied. Disturbed and undisturbed transects were analyzed separately. In all vegetation analyses, the cover class variable for each species was converted to the percentage of cover represented by the midpoint of the class range (for example, class 2 was converted to 18 percent); Class $\mathrm{P}$ was assigned a cover value of 0.5 percent (table 1). The dependent variables for vegetation analyses were species richness, percentage of total vegetation cover, and percentage of Cyperus cover, defined as the sum of Cyperus iria, Cyperus erythrorhizos, and Cyperaceae (plants identified to family level only) cover values. To further investigate the effect of soil elevation, transects were pooled, and a one-way ANOVA was performed by using elevation class as an independent variable. Disturbed and undisturbed transects were again analyzed separately, and repeated measures techniques were applied for times 2-4. The effect of soil disturbance and disturbance by elevation on vegetation for the five transects that included a parallel transect impacted by soil scraping were examined with paired ttests.

The impact of the 1995 drawdown on pool vegetation in 1996 was examined by characterizing the plant community at two times during normal pool stage (times 1 and 5 [June 1995 and 1996]). Data from disturbed transects were not included in these analyses. The community was characterized two ways: as species present in 20 or more quadrats summed across all transects at either time, and as species with total cover greater than 400 percent summed across all transects at either time. The nonnative species Bacopa egensis was also included, regardless of its frequency or cover value. The quadrat count data were adjusted to equal sample sizes and analyzed as a categorical two-way ANOVA by using a chi-square test, and the cover data were analyzed by using paired t-tests.

The effect of elevation on seed bank species richness was examined by using a one-way ANOVA with elevation class as the independent variable. Seed bank species richness was compared to that of the standing crop in both June and October by using paired t-tests; paired ttests were also conducted to describe the effect of disturbance on seed bank species richness (October samples).

Two-way ANOVA was used to examine the effect of transect and elevation (nested within quadrat) on soil variables, with dependent variables of soil percentage of carbon, percentage of nitrogen, nutrient concentration ( $\mathrm{P}, \mathrm{K}, \mathrm{Ca}, \mathrm{Mg}, \mathrm{Na}, \mathrm{Cu}, \mathrm{Fe}, \mathrm{Mn}$, and $\mathrm{Zn}$ ), and organic matter; no analyses of soil percentage of sand, silt, and clay were performed because only a single data point per transect was obtained for each variable. Paired t-tests were used to examine the effect of disturbance on soil percent carbon and nitrogen content and percent organic matter.

\section{Results}

Transect and Plant Community Descriptions

Plants quickly colonized undisturbed areas of the drawdown zone (figs. 3 and 4). The GPS location of the base quadrat for the 19 transects and length of each transect are listed in table 2 . Relative elevation of the quadrat locations in reference to the transect base station ranged from $30.48 \mathrm{~cm}(1 \mathrm{ft})$ to $-5.49 \mathrm{~cm}(-0.18 \mathrm{ft})$ (appendix 1). We identified 63 vascular plants and 2 bryophytes within quadrats (table 3 ); 13 of the vascular plants were identified only to genera or 
family level, and one species was unknown. Species frequency, defined as the percentage of total quadrats (all transects) in which a species was found, ranged from 0 to 89.6 percent (Wolffia sp., June 1996) during the study (appendix 2); total cover by species summed across all transects ranged from 0 to 3,324 percent (Ludwigia peploides, August 1995) (appendix 3). While flooded in June 1995 and 1996, the most frequent species and species with the highest cover were primarily submersed or floating; during the drawdown, emergent species became common (table 4 and fig. 5).
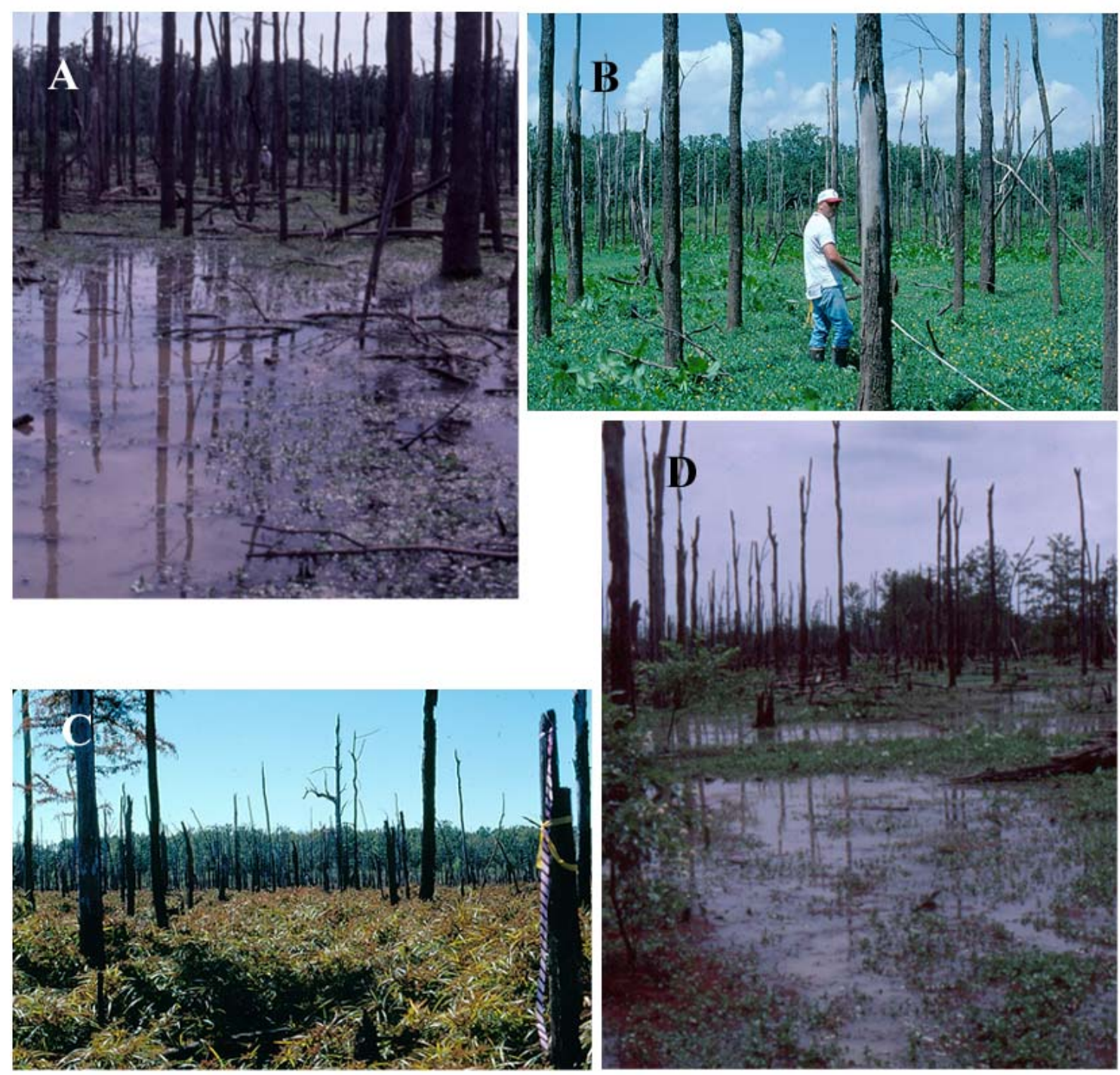

Figure 3. View of transect 8 (specific location on the transect varied with each photograph). A, June 1995. B, August 1995. C, October 1995. D, June 1996. 


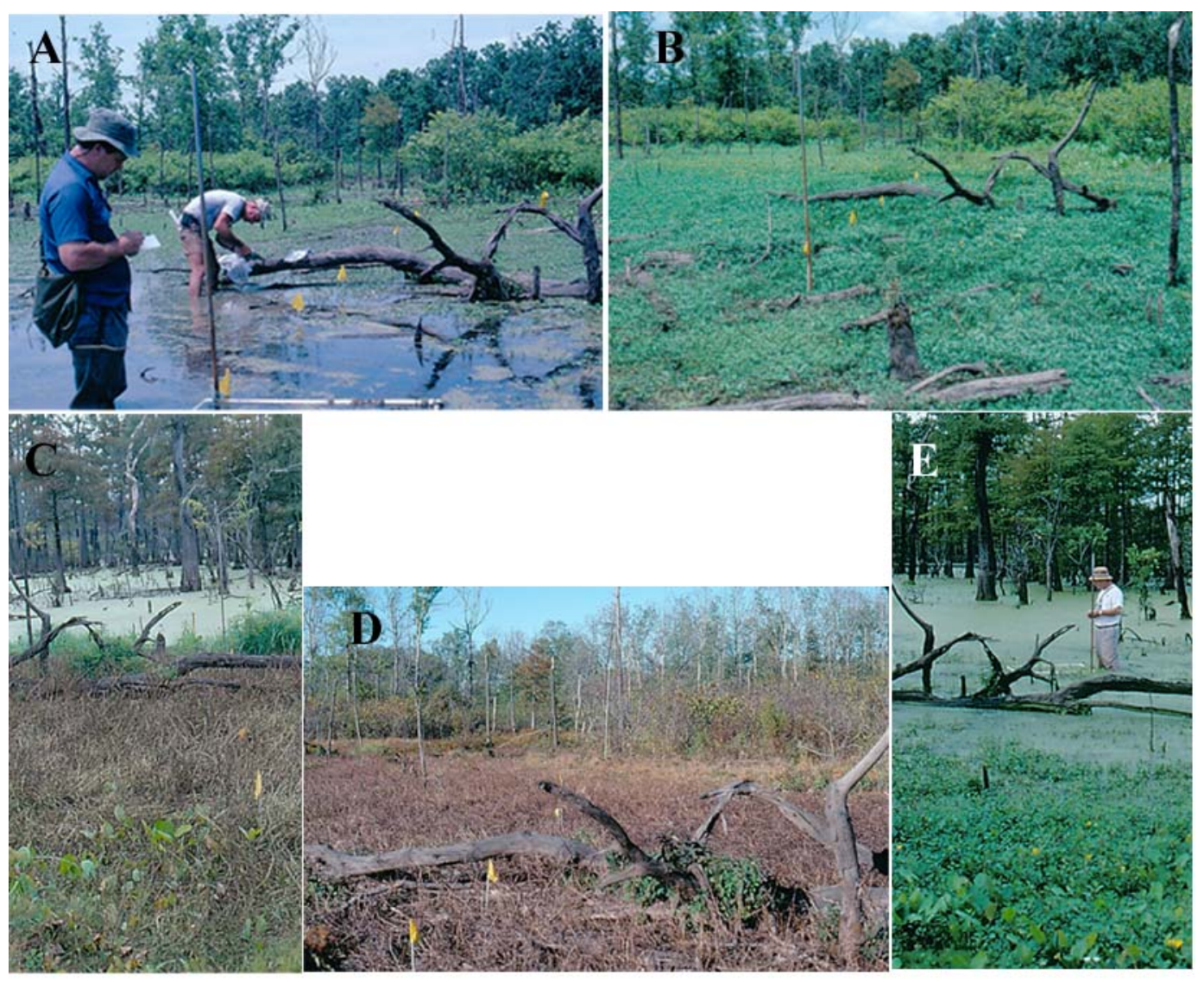

Figure 4. View of transect 10 (specific location on the transect varied with each photograph). A, June 1995. B, August 1995. C, September 1995. D, October 1995. E, June 1996. 
Table 2. Location and description of permanent vegetation transects.

[Paired transects that included a soil disturbance treatment are indicated by letters next to the transect number; $\mathrm{a}=$ undisturbed, $\mathrm{b}=$ disturbed. Abbreviations are: Trans $=$ transect number, Quads $=$ number of quadrats located on transect, Northing and Easting are UTM coordinates, Bearing is compass bearing, and Length is distance from base marker to final quadrat]

\begin{tabular}{lccccc}
\hline Trans & Quad & Northing & Easting & Bearing & $\begin{array}{c}\text { Length } \\
(\mathrm{m})\end{array}$ \\
\hline 1 & 7 & 578980 & 3659052 & 20 & 29.4 \\
$2 \mathrm{a}$ & 7 & 577580 & 3660694 & 60 & 51.1 \\
$2 \mathrm{~b}$ & 7 & -- & -- & 60 & 64.9 \\
$3 \mathrm{a}$ & 7 & 576991 & 3661631 & 90 & 111.0 \\
$3 \mathrm{~b}$ & 6 & -- & -- & 90 & 96.0 \\
$4 \mathrm{a}$ & 7 & 578053 & 3663084 & 105 & 26.9 \\
$4 \mathrm{~b}$ & 7 & -- & -- & 105 & 19.6 \\
5 & 7 & 578910 & 3663903 & 179 & 51.5 \\
6 & 6 & 580431 & 3665170 & 167 & 77.9 \\
7 & 6 & 579314 & 3661738 & 208 & 82.3 \\
8 & 7 & 581031 & 3662675 & 55 & 223.6 \\
9 & 7 & 582413 & 3662114 & 348 & 134.3 \\
10 & 7 & 582620 & 3661534 & 194 & 22.0 \\
11 & 7 & 582333 & 3660180 & 96 & 36.7 \\
12 & 6 & 584843 & 3666320 & 0 & 19.4 \\
$14 \mathrm{a}$ & 7 & 585851 & 3666656 & 270 & 69.0 \\
$14 \mathrm{~b}$ & 7 & -- & -- & 270 & 46.4 \\
$15 \mathrm{a}$ & 7 & 585845 & 3664597 & 280 & 32.0 \\
$15 \mathrm{~b}$ & 7 & -- & -- & 280 & 29.6 \\
\hline
\end{tabular}


Table 3. Plant species identified at 19 transects at Felsenthal Navigation Pool, Felsenthal National Wildlife Refuge, Crossett, Ark.

[Plant names according to Integrated Taxonomic Information System (2007). Some plants were identified to family or genus only. Life form designations are: $\mathrm{E}=$ emergent herbaceous, $\mathrm{F}=$ floating-leaved, $\mathrm{S}=$ submersed aquatic, $\mathrm{W}=$ woody]

\begin{tabular}{|c|c|c|c|}
\hline Species & $\begin{array}{c}\text { Life } \\
\text { Form }\end{array}$ & Common Name & Code \\
\hline \multicolumn{4}{|l|}{ Vascular: } \\
\hline Ammannia coccinea Rottb. & $\mathrm{E}$ & purple ammannia & Amco \\
\hline Azolla caroliniana Willd. & $\mathrm{F}$ & Carolina mosquitofern & Azca \\
\hline Bacopa egensis (Poepp.) Pennell & $\mathrm{E}$ & Brazilian waterhyssop & Baeg \\
\hline Bacopa rotundifolia (Michx.) Wettst. & $\mathrm{E}$ & disk waterhyssop & Baro \\
\hline Bidens aristosa (Michx.) Britt. & $\mathrm{E}$ & bearded beggarticks & Biar \\
\hline Brunnichia ovata (Walt.) Shinners & $\mathrm{W}$ & redvine & Brov \\
\hline Cabomba caroliniana Gray & $\mathrm{S}$ & Carolina fanwort & Caca \\
\hline Carex sp. & $\mathrm{E}$ & sedge & Casp \\
\hline Cephalanthus occidentalis L. & $\mathrm{W}$ & common buttonbush & Ceoc \\
\hline Ceratophyllum demersum L. & $\mathrm{S}$ & common hornwort & Cede \\
\hline Cyperaceae & $\mathrm{E}$ & sedge & $\mathrm{Cy}$ \\
\hline Cyperus erythrorhizos Muhl. & $\mathrm{E}$ & redroot flatsedge & Cyer \\
\hline Cyperus iria L. & $\mathrm{E}$ & ricefield flatsedge & Cyir \\
\hline Diodia teres Walt. & $\mathrm{E}$ & rough buttonweed & Dite \\
\hline Diospyros virginiana L. & $\mathrm{W}$ & common persimmon & Divi \\
\hline Echinochloa crus-galli (L.) Beauv. & $\mathrm{E}$ & barnyard grass & Eccr \\
\hline Echinodorus cordifolius (L.) Griseb. & $\mathrm{E}$ & creeping burhead & Ecco \\
\hline Eclipta prostrata (L.) L. & $\mathrm{E}$ & yerba de tajo & Ecpr \\
\hline Eleocharis microcarpa Torr. & $\mathrm{E}$ & smallfruit spikerush & Elmi \\
\hline Eleocharis obtusa (Willd.) J.A. Schultes & $\mathrm{E}$ & blunt spikerush & Elob \\
\hline Fimbristylis miliacea (L.) Vahl & $\mathrm{E}$ & grasslike fimbry & Fimi \\
\hline Gleditsia aquatica Marsh. & $\mathrm{W}$ & water locust & Glaq \\
\hline Heteranthera reniformis Ruiz \& Pavon & $\mathrm{E}$ & kidneyleaf mudplantain & Here \\
\hline Hibiscus sp. & $\mathrm{E}$ & rosemallow & Hisp \\
\hline Hydrolea quadrivalvis Walt. & $\mathrm{E}$ & waterpod & Hyqu \\
\hline Ipomoea sp. & $\mathrm{E}$ & morning-glory & Ipsp \\
\hline Juncus sp. & $\mathrm{E}$ & rush & Jusp \\
\hline Leersia oryzoides (L.) Sw. & $\mathrm{E}$ & rice cutgrass & Leor \\
\hline $\begin{array}{l}\text { Leptochloa fascicularis var. fascicularis } \\
\text { (Lam.) Gray }\end{array}$ & $\mathrm{E}$ & bearded sprangletop & Lefa \\
\hline Limnobium spongia (Bosc) L.C. Rich. ex Steud. & $\mathrm{F}$ & frogbite & Lisp \\
\hline Lindernia dubia (L.) Pennell & $\mathrm{E}$ & yellowseed false pimpernel & Lidu \\
\hline Ludwigia decurrens Walt. & $\mathrm{E}$ & wingleaf waterprimrose & Lude \\
\hline Ludwigia leptocarpa (Nutt.) Hara & $\mathrm{E}$ & anglestem waterprimrose & Lule \\
\hline
\end{tabular}




\begin{tabular}{|c|c|c|c|}
\hline Species & $\begin{array}{c}\text { Life } \\
\text { Form }\end{array}$ & Common Name & Code \\
\hline Ludwigia palustris (L.) Ell. & $\mathrm{E}$ & marsh seedbox & Lupa \\
\hline Ludwigia peploides (Kunth) Raven & $\mathrm{E}$ & creeping waterprimrose & Lupe \\
\hline Ludwigia sphaerocarpa Ell. & $\mathrm{E}$ & $\begin{array}{c}\text { globefruit primrose- } \\
\text { willow }\end{array}$ & Lusp \\
\hline Ludwigia uruguayensis (Camb.) Hara & $\mathrm{E}$ & Uruguay waterprimrose & Luur \\
\hline Mikania scandens (L.) Willd. & $\mathrm{E}$ & climbing hempweed & Misc \\
\hline Mimosa strigillosa Torr. \& Gray & $\mathrm{E}$ & herbaceous mimosa & Mist \\
\hline Myriophyllum sp. & $\mathrm{S}$ & watermilfoil & Mysp \\
\hline Najas sp. & $\mathrm{S}$ & water nymph & Nasp \\
\hline Panicum sp. & $\mathrm{E}$ & panicgrass & Pasp \\
\hline Planera aquatica J. F. Gmel. & $\mathrm{W}$ & planertree & Plaq \\
\hline Pluchea foetida (L.) DC & $\mathrm{E}$ & stinking camphorweed & Plfo \\
\hline Poa annua L. & $\mathrm{E}$ & annual bluegrass & Poan \\
\hline Poa autumnalis Muhl. ex. Ell. & $\mathrm{E}$ & autumn bluegrass & Poau \\
\hline Poaceae & $\mathrm{E}$ & grasses & Po \\
\hline Potamogeton sp. & $\mathrm{S}$ & pondweed & Posp \\
\hline Rhynchospora sp. & $\mathrm{E}$ & beaksedge & Rhsp \\
\hline Sagittaria graminea Michx. & $\mathrm{E}$ & grass-leaf arrowhead & Sagr \\
\hline Sagittaria latifolia Willd. & $\mathrm{E}$ & broadleaf arrowhead & Sala \\
\hline Sagittaria sp. & $\mathrm{E}$ & arrowhead & Sasp \\
\hline Sesbania exaltata (Raf.) Rydb. ex A.W. Hill & $\mathrm{E}$ & hemp sesbania & Seex \\
\hline Sphenoclea zeylanica Gaertn. & $\mathrm{E}$ & chickenspike & Spze \\
\hline Spirodela polyrrhiza (L.) Schleid. & $\mathrm{F}$ & greater duckweed & Sppo \\
\hline Taxodium distichum (L.) L.C. Rich. & $\mathrm{W}$ & bald cypress & Tadi \\
\hline Triadenum walteri (J.G. Gmel.) Gleason & $\mathrm{E}$ & $\begin{array}{l}\text { greater marsh St. } \\
\text { Johnswort }\end{array}$ & Trwa \\
\hline Utricularia gibba L. & $\mathrm{S}$ & humped bladderwort & Utgi \\
\hline Utricularia inflata Walt. & $\mathrm{S}$ & swollen bladderwort & Utin \\
\hline Vitis rotundifolia Michx. & $\mathrm{W}$ & muscadine grape & Viro \\
\hline Wolffia sp. & $\mathrm{F}$ & watermeal & Wosp \\
\hline Xanthium strumarium L. & $\mathrm{E}$ & $\begin{array}{l}\text { rough cocklebur } \\
\text { unknown dicot }\end{array}$ & $\begin{array}{l}\text { Xast } \\
\text { Uk }\end{array}$ \\
\hline \multicolumn{4}{|l|}{ Bryophytes: } \\
\hline Riccia sp. & & riccia & Rici \\
\hline Ricciocarpos sp. & & ricciocarpus & Rico \\
\hline
\end{tabular}


Table 4. Five most frequently-occurring species and five species with the highest total cover at five sampling times, listed in decreasing order.

[Some plants were identified to family or genus only. A slash indicates species with equal frequency or total cover measures]

\begin{tabular}{|c|c|c|}
\hline Month & Frequency & Total Cover \\
\hline June 1995 & $\begin{array}{l}\text { Spirodela polyrrhiza } \\
\text { Ludwigia palustris } \\
\text { Limnobium spongia } \\
\text { Utricularia gibba } \\
\text { Wolffia sp. / Eleocharis microcarpa }\end{array}$ & $\begin{array}{l}\text { Spirodela polyrrhiza } \\
\text { Eleocharis microcarpa } \\
\text { Najas sp. } \\
\text { Ludwigia palustris } \\
\text { Limnobium spongia }\end{array}$ \\
\hline August 1995 & $\begin{array}{l}\text { Ludwigia peploides } \\
\text { Eleocharis microcarpa } \\
\text { Cyperaceae } \\
\text { Spirodela polyrrhiza / Ludwigia palustris } \\
\text { Bidens aristosa }\end{array}$ & $\begin{array}{l}\text { Ludwigia peploides } \\
\text { Eleocharis microcarpa } \\
\text { Ludwigia palustris } \\
\text { Sagittaria latifolia } \\
\text { Spirodela polyrrhiza }\end{array}$ \\
\hline September 1995 & $\begin{array}{l}\text { Ludwigia peploides } \\
\text { Cephalanthus occidentalis } \\
\text { Cyperus iria } \\
\text { Bidens aristosa } \\
\text { Eleocharis microcarpa }\end{array}$ & $\begin{array}{l}\text { Ludwigia peploides } \\
\text { Cyperus iria } \\
\text { Eleocharis microcarpa } \\
\text { Cephalanthus occidentalis } \\
\text { Sphenoclea zeylanica }\end{array}$ \\
\hline October 1995 & $\begin{array}{l}\text { Cyperus erythrorhizos } \\
\text { Cephalanthus occidentalis } \\
\text { Triadenum walteri } \\
\text { Eleocharis microcarpa / Eclipta prostata } \\
\text { Bidens aristosa }\end{array}$ & $\begin{array}{l}\text { Cyperus erythrorhizos } \\
\text { Cephalanthus occidentalis } \\
\text { Eleocharis microcarpa } \\
\text { Fimbristylus miliaceae / } \\
\text { Triadenum walteri } \\
\text { Leptochloa fascicularis v. } \\
\text { fascicularis }\end{array}$ \\
\hline June 1996 & $\begin{array}{l}\text { Wolffia sp. } \\
\text { Spirodela polyrrhiza } \\
\text { Utricularia inflata } \\
\text { Ludwigia peploides } \\
\text { Limnobium spongia / Azolla caroliniana }\end{array}$ & $\begin{array}{l}\text { Utricularia inflata } \\
\text { Wolffia sp. } \\
\text { Spirodela polyrrhiza } \\
\text { Ludwigia peploides } \\
\text { Potomogeton sp. }\end{array}$ \\
\hline
\end{tabular}




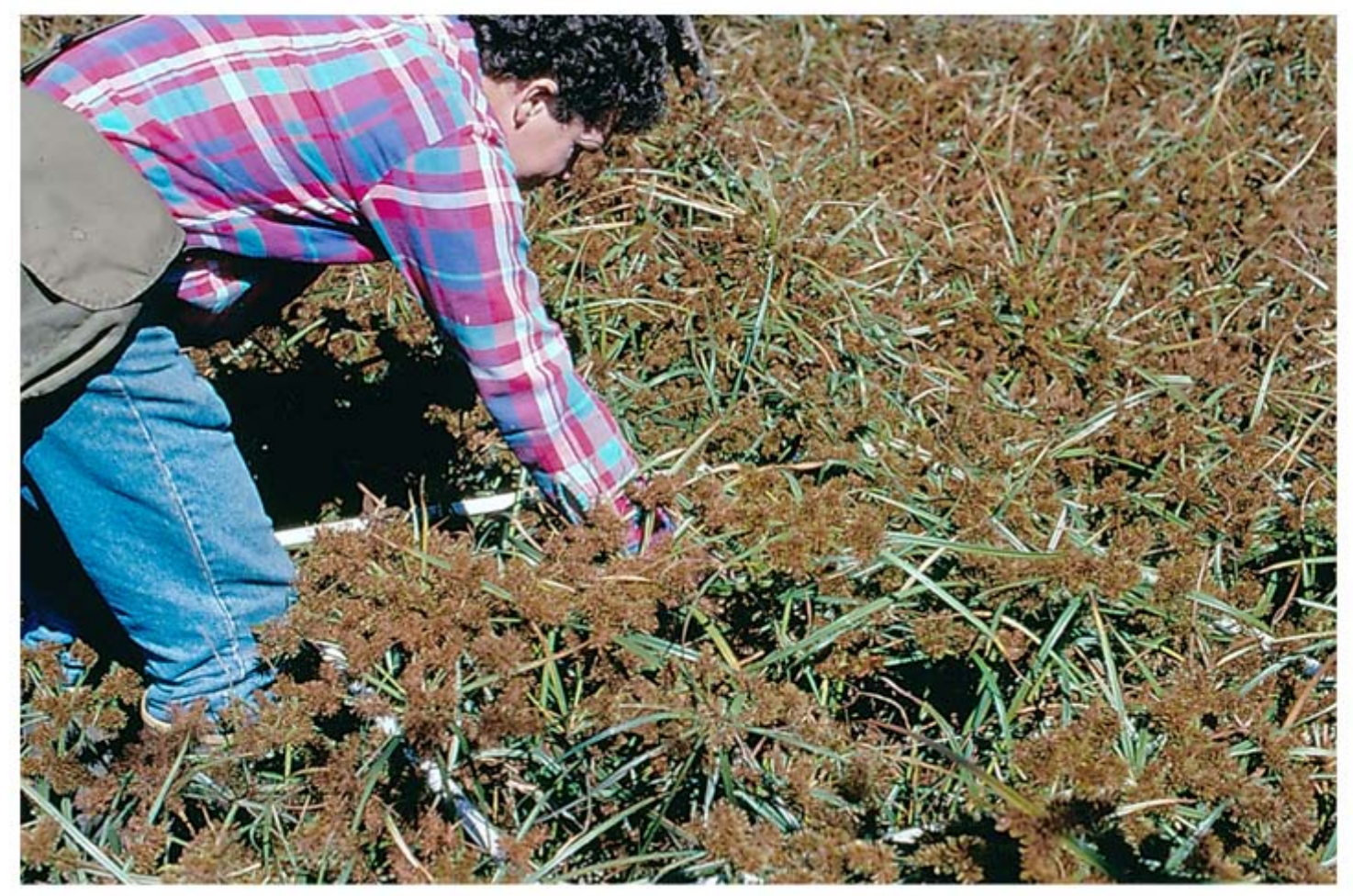

Figure 5. Growth of Cyperus erythrorhizos at transect 6 in October 1995.

Species richness within quadrats ranged from 0 to a maximum of 14 (June 1995), 10 (August 1995), 13 (September 1995), 9 (October 1995), and 10 (June 1996); mean species richness was higher during flooded conditions compared to the drawdown at several transects (fig. 6).

Patterns in total cover by transect (fig. 7) resembled those of species richness. Cyperus species cover was very sparse prior to the drawdown, but composed more than 50 percent of total cover in some transects in September and October (fig. 8); Cyperus was absent during sampling in June 1996. Overall means for the three vegetation response measures in the 14 undisturbed transects exceeded those in disturbed transects at all measurement times (table 5). 


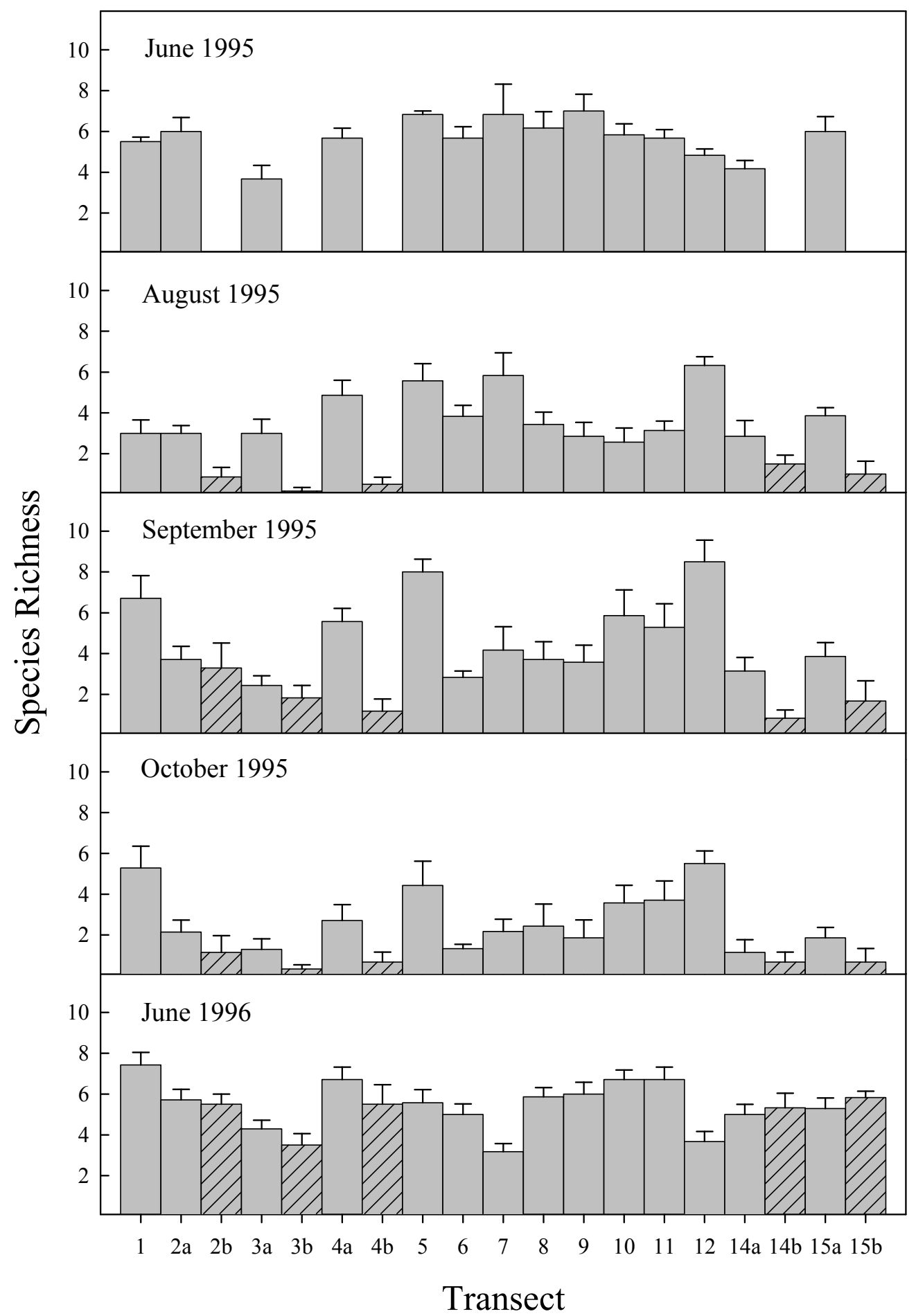

Figure 6. Total species richness (mean $\pm 1 \mathrm{SE}$ ) by transect at five times. The letter "a" indicates the undisturbed transect for the five paired transects; disturbed transects are indicated by the letter "b" and by hatching. 


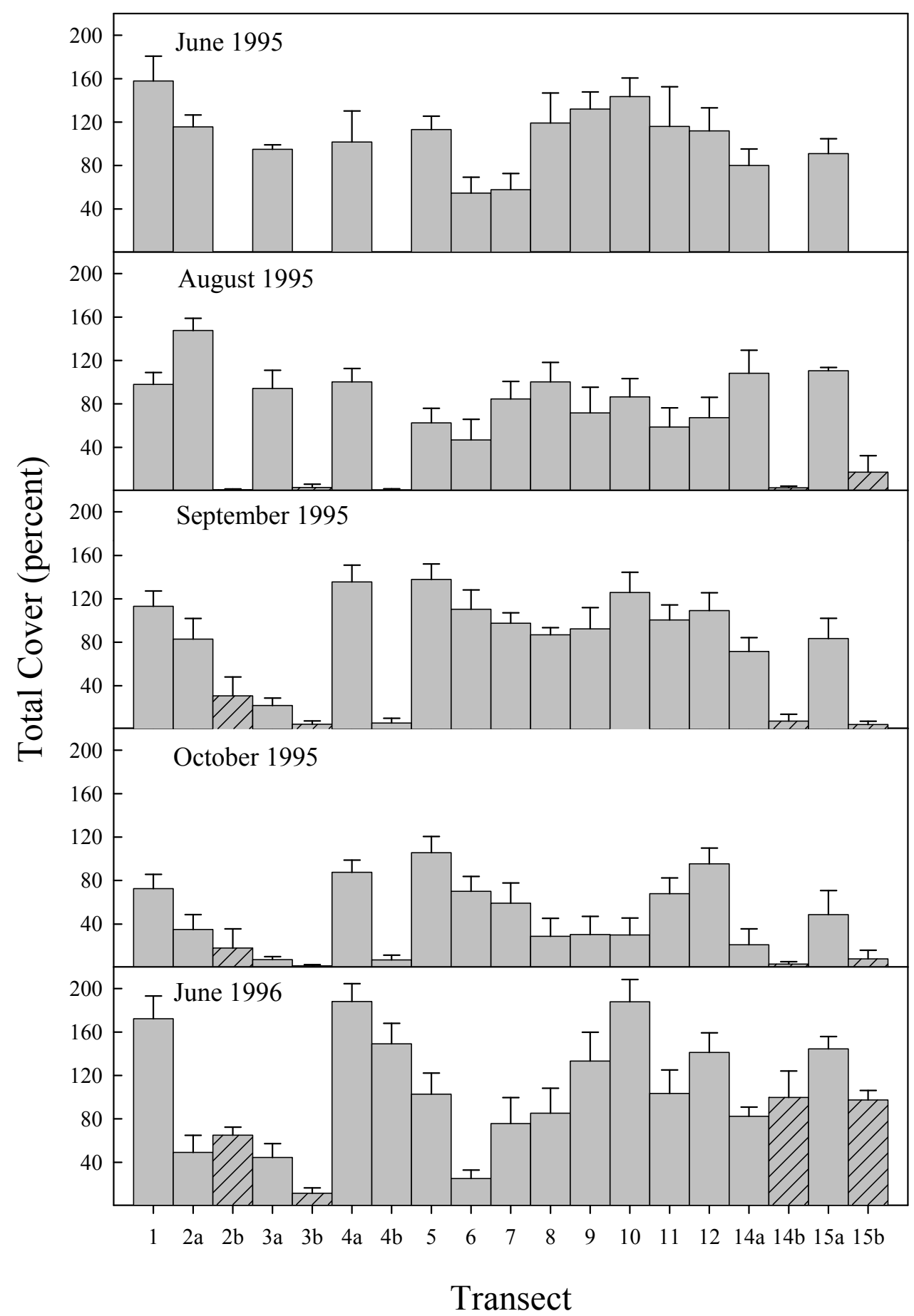

Figure 7. Total vegetation cover (mean $\pm 1 \mathrm{SE}$ ) by transect at five times. The letter "a" indicates the undisturbed transect for the five paired transects; disturbed transects are indicated by the letter "b" and by hatching. Cover can exceed 100 percent because various species may be present in different strata. 


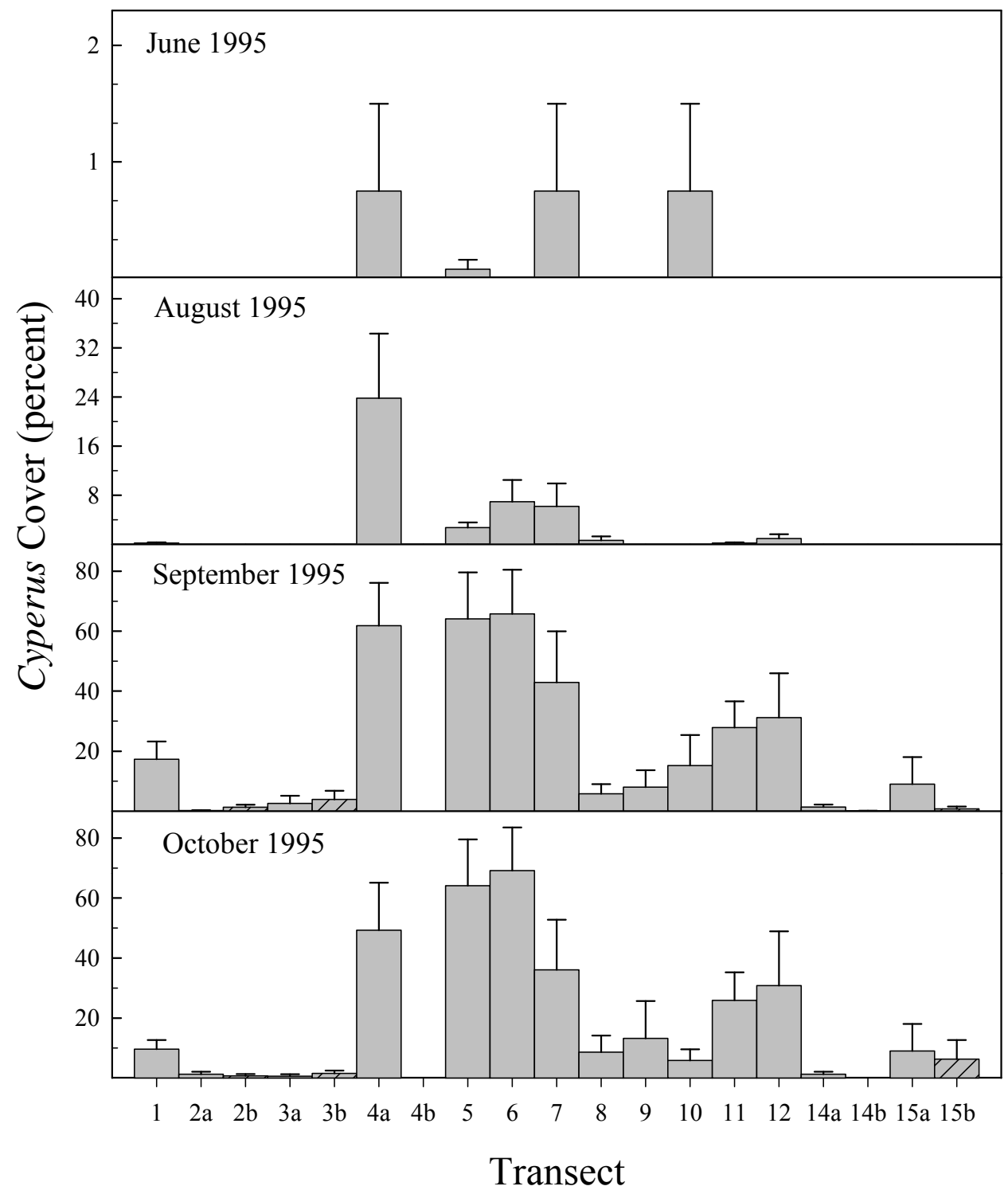

Figure 8. Total Cyperus cover (mean \pm 1 SE; includes Cyperus erythrorhizos, Cyperus iria, and Cyperaceae) by transect at five times. The letter "a" indicates the undisturbed transect for the five paired transects; disturbed transects are indicated by the letter "b" and by hatching. Note different scales on y axis. 
Table 5. Overall vegetation response (mean $\pm 1 \mathrm{SE})$ at five sampling times on undisturbed $(\mathrm{n}=$ 84 in June 1995; $n=95$ at all other times) and four sampling times on disturbed $(n=31)$ sampling quadrats.

[Abbreviations are: $\mathrm{Rich}=$ species richness, $\mathrm{Cov}=$ total vegetation cover (percent), and $\mathrm{CyCov}$ = Cyperus cover (percent)]

\begin{tabular}{crrr}
\hline Time & Rich & \multicolumn{1}{c}{ Cov } & \multicolumn{1}{c}{ CyCov } \\
\hline Undisturbed Transects & & & \\
June 1995 & $5.7 \pm 0.2$ & $106.4 \pm 5.8$ & $0.2 \pm 0.1$ \\
August 1995 & $3.8 \pm 0.2$ & $89.0 \pm 4.8$ & $2.9 \pm 1.0$ \\
September 1995 & $4.8 \pm 0.3$ & $97.5 \pm 4.8$ & $24.5 \pm 3.5$ \\
October 1995 & $2.8 \pm 0.3$ & $53.6 \pm 4.8$ & $22.5 \pm 3.5$ \\
June 1996 & $5.6 \pm 0.2$ & $110.6 \pm 7.0$ & $0.0 \pm 0.0$ \\
& & & \\
Disturbed Transects & & & \\
August 1995 & $0.8 \pm 0.2$ & $11.1 \pm 4.5$ & $1.2 \pm 0.6$ \\
September 1995 & $1.8 \pm 0.4$ & $7.8 \pm 4.3$ & $1.7 \pm 1.2$ \\
October 1995 & $0.7 \pm 0.3$ & $81.9 \pm 10.5$ & $0.0 \pm 0.0$ \\
June 1996 & $5.0 \pm 0.3$ & & \\
\hline
\end{tabular}

Transect and Elevation Effects

In June 1995, when the pool was at base level, vegetation response varied by elevation (table 6). Significant responses consisted of greater total cover (percentage) at low elevation (217.3 \pm 39.8; mean $\pm 1 \mathrm{SE})$ compared to high elevation $(65.5 \pm 22.5)$ in transect 11 , and greater total cover at high elevation $(139.8 \pm 28.8)$ compared to low elevation $(25.5 \pm 10.5)$ in transect $4 a$. In June 1996, when the pool again was flooded to base level, vegetation response (richness and total cover) varied by transect location for undisturbed transects (table 6). Mean species richness in undisturbed transects ranged from $3.2 \pm 0.4$ (transect 7 ) to $7.4 \pm 0.6$ (transect 1), with overlap among transects with intermediate values (fig. 6). Although there was a significant overall elevation effect for disturbed transects (table 6), when the alpha level was adjusted by the number of pairwise comparisons (five comparisons, $\alpha=0.01$ ), no transects were significantly different from the others. 
Table 6. Results of an analysis of variance (F values) of undisturbed and disturbed transects during base pool water stage in June 1995 and 1996.

[Abbreviations are: Trans $=$ transect and Elev $=$ elevation class. The significance value is $\left.P<0.05^{*}\right]$

\begin{tabular}{lcc}
\hline \multicolumn{1}{c}{ Source } & June 1995 & June 1996 \\
\hline Undisturbed Transects & & \\
Trans & 1.32 & $3.46^{*}$ \\
Elev(Trans) & $1.64^{*}$ & 1.51 \\
Disturbed Transects & & \\
Trans & -- & 2.51 \\
Elev(Trans) & -- & $3.15^{* 1}$ \\
\hline
\end{tabular}

${ }^{1}$ Pairwise comparisons not significant.

During the drawdown, transect and the time and elevation interaction significantly affected vegetation response on undisturbed transects; vegetation on the disturbed transects was not affected (table 7). For the undisturbed transects, there were often overlapping groups of transects with similar mean values for each of the vegetation variables (fig. 9), and no consistent patterns in groupings across time were apparent. Significant elevation effects at a particular time were found in undisturbed transects for total cover in August and for Cyperus cover in August and September. In August, total cover (percentage) was greater in the high $(98.2 \pm 23.8)$ compared to low (5.3 \pm 4.8$)$ elevation class in transect 9; no other significant responses were identified for this variable. Elevation affected Cyperus cover in three transects, 5, 7, and 12, in August and September; in all cases, cover was lesser at high compared to low elevation. Looking at response over time, elevation significantly affected vegetation response for seven time intervals (table 8). While the results are difficult to present in detail, general patterns were evident. Richness increased from August to September at both elevation classes, but the magnitude of the increase was greater at low compared to high elevations. From September to October, richness decreased at high elevation at all four transects, while at low elevation it decreased at three transects and remained steady at the fourth. At two of the transects where richness decreased over time at both elevations, the magnitude of change was greater at low compared to high elevation. Total cover from August to September increased or remained relatively constant at low elevations, but decreased at high elevations; this pattern was also evident from September to October with the exception of transect 1 , where cover decreased at both elevations. Cyperus cover increased at both time intervals, to a greater magnitude at low compared to high elevations. 
Table 7. Results of repeated measures multiple analysis of variance ( $\mathrm{F}$ values) of undisturbed and disturbed transects during pool drawdown, in August, September, and October 1995.

[Abbreviations are: Trans $=$ transect and Elev $=$ elevation class. Significance values are $P<0.05^{*}$ and $\left.P<0.0001^{* *}\right]$

\begin{tabular}{lcc}
\hline \multicolumn{1}{c}{ Source } & Undisturbed Transects & Disturbed Transects \\
\hline Trans & $1.94^{*}$ & 0.73 \\
Elev(Trans) & $2.44^{* *}$ & 1.33 \\
Time $^{1}$ & -- & -- \\
Time*Trans $^{*}$ & 1.03 & -- \\
Time*Elev(Trans) $^{*}$ & $2.67^{* *}$ & 0.74 \\
\hline
\end{tabular}

${ }^{1}$ Insufficient degrees of freedom to estimate effect. 
A. August 1995

Species Richness

$\begin{array}{llllllllllllll}12 & 7 & 5 & 4 \mathrm{a} & 15 \mathrm{a} & 6 & 8 & 11 & 1 & 3 \mathrm{a} & 2 \mathrm{a} & 9 & 14 \mathrm{a} & 10\end{array}$

Total Cover

\begin{tabular}{llllllllllllll}
$2 \mathrm{a}$ & $15 \mathrm{a}$ & $14 \mathrm{a}$ & $4 \mathrm{a}$ & 8 & 1 & $3 \mathrm{a}$ & 10 & 7 & 9 & 12 & 5 & 11 & 6 \\
\hline
\end{tabular}

Cyperus Cover

\begin{tabular}{llllllllllllll}
$4 \mathrm{a}$ & 6 & 7 & 5 & 12 & 8 & 11 & 1 & $15 \mathrm{a}$ & 10 & $2 \mathrm{a}$ & $3 \mathrm{a}$ & $14 \mathrm{a}$ & 9 \\
\hline
\end{tabular}

B. September 1995

Species Richness

$\begin{array}{llllllllllllll}12 & 5 & 1 & 10 & 4 \mathrm{a} & 11 & 7 & 15 \mathrm{a} & 2 \mathrm{a} & 8 & 9 & 14 \mathrm{a} & 6 & 3 \mathrm{a}\end{array}$

Total Cover

\begin{tabular}{llllllllllllll}
5 & $4 \mathrm{a}$ & 10 & 1 & 6 & 12 & 11 & 7 & 9 & 8 & $15 \mathrm{a}$ & $2 \mathrm{a}$ & $14 \mathrm{a}$ & $3 \mathrm{a}$ \\
\hline
\end{tabular}

Cyperus Cover

$\begin{array}{llllllllllllll}6 & 5 & 4 \mathrm{a} & 7 & 12 & 11 & 1 & 10 & 15 \mathrm{a} & 9 & 8 & 3 \mathrm{a} & 14 \mathrm{a} & 2 \mathrm{a}\end{array}$

C. October 1995

Species Richness

\begin{tabular}{llllllllllllll}
12 & 1 & 5 & 11 & 10 & $4 \mathrm{a}$ & 8 & 7 & $2 \mathrm{a}$ & $15 \mathrm{a}$ & 9 & 6 & $3 \mathrm{a}$ & $14 \mathrm{a}$ \\
\hline
\end{tabular}

Total Cover

\begin{tabular}{lllllllllllllll}
5 & 12 & $4 \mathrm{a}$ & 1 & 6 & 11 & 7 & $15 \mathrm{a}$ & $2 \mathrm{a}$ & 9 & 10 & 8 & $14 \mathrm{a}$ & $3 \mathrm{a}$ \\
\hline & $\mathbf{1}$
\end{tabular}

Cyperus Cover

\begin{tabular}{llllllllllllll}
6 & 5 & $4 a$ & 7 & 12 & 11 & 9 & 1 & $15 a$ & 8 & 10 & $2 a$ & $14 a$ & $3 a$ \\
\hline
\end{tabular}

Figure 9. Duncan's multiple range comparisons from an analysis of variance of vegetation response at undisturbed transects (noted by an "a" in paired transects) along the edge of Felsenthal Navigation Pool. Lines connect transects with similar means for the three variablesspecies richness, total cover, and Cyperus cover - at three times during the pool drawdown. Transects are ordered from highest to lowest value. 
Table 8. Results of repeated measures analysis of variance of elevation effect on vegetation at undisturbed transects (noted by an "a" in paired transects) at Felsenthal Navigation Pool. Transects listed are those that had a significant effect on the response over the time interval indicated.

[Times are: 2 = August 1995; 3 = September 1995; and $4=$ October 1995]

\begin{tabular}{lcr}
\hline Response & Time Interval & Transect \\
\hline Species richness & $2-3$ & $1,9,11$ \\
Total cover & $3-4$ & $1,5,7,10$ \\
& $2-3$ & $2 \mathrm{a}, 7,14 \mathrm{a}, 15 \mathrm{a}$ \\
Cyperus cover & $2-4$ & $7,8,9$ \\
& $3-4$ & $1,6,9$ \\
& $2-3$ & $5,7,12$ \\
\hline
\end{tabular}

When undisturbed transects were pooled, elevation did not affect vegetation response in June $1995(P=0.2869)$ or June $1996(P=0.3595)$. Repeated measures analysis of data collected during the drawdown indicated a significant elevation effect $(P=0.0225)$ across time for the undisturbed transects. These results were consistent with those from the earlier analyses, indicating that species richness and total cover increased from August to September, to a greater extent in low compared to high elevations. Cyperus cover increased from August to September at low elevation but decreased at high elevation. Elevation did not affect vegetation response when disturbed transects were pooled, either during the drawdown $(P=0.3573)$ or in June $1996(P=$ $0.5620)$.

\section{Disturbance and Elevation Effects}

Disturbance, which consisted of scraping the soil surface with a bulldozer, significantly affected vegetation response during the pool drawdown on the five paired transects (fig. 10 and table 9). Soil disturbance decreased species richness at all three times and decreased total cover in August and September (table 10). Examining disturbance by elevation class, species richness was greater in undisturbed compared to disturbed transects at high elevation all three times during the drawdown and in August and October at low elevations (fig. 11). Total cover was greater at undisturbed transects in both elevation classes in August and September; in October, however, cover was greater in undisturbed transects only at low elevations (fig. 12). Disturbance did not significantly affect Cyperus species cover in either elevation class (fig. 13). In June 1996 , no effect of disturbance on species richness $(P=0.4658)$ or total cover $(P=0.2874)$ was identified. 

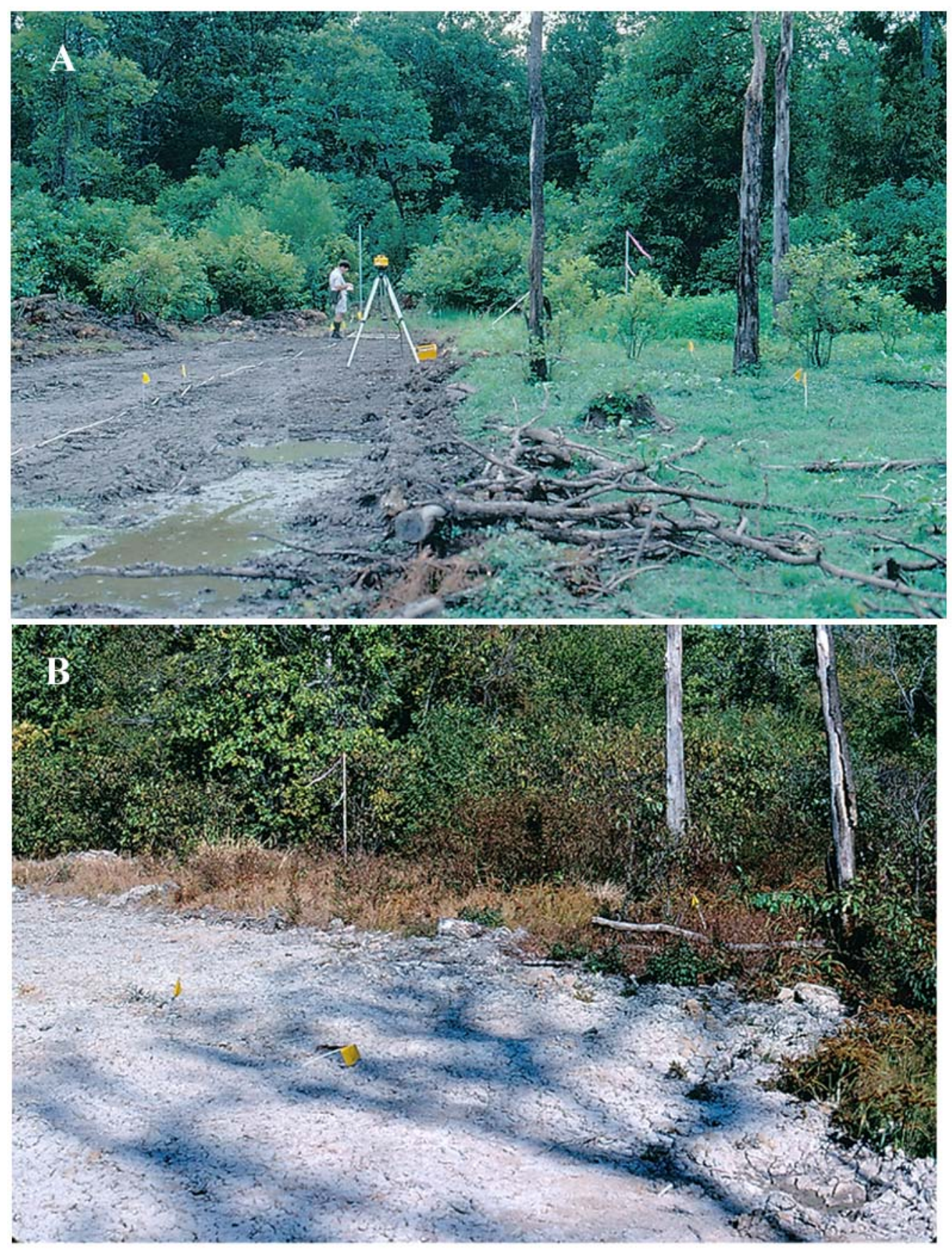

Figure 10. View of transect $4 \mathrm{~b}$ (specific location on the transect varied with each photograph). A, August 1995. B, October 1995. 
Table 9. Results of a paired t-test analysis ( $t$ values) of disturbance effect on vegetation during pool drawdown, in August, September, and October 1995, at five paired transects. Significance value is $P<0.05^{*}$.

\begin{tabular}{lccc}
\hline & & & \\
Month & Species Richness & Total Cover & Cyperus Cover \\
\hline August & $5.47^{*}$ & $10.56^{*}$ & 1.00 \\
September & $2.76^{*}$ & $3.72^{*}$ & 1.14 \\
October & $4.41^{*}$ & 2.43 & 1.09 \\
\hline
\end{tabular}

Table 10. Vegetation response (mean $\pm 1 \mathrm{SE}$ ) at five undisturbed ("undisturb") and five disturbed ("disturb") transects. Data were collected in August, September, and October 1995, and June 1996. Significant differences between undisturbed and disturbed transects from paired t-test analysis are indicated by dissimilar letters.

\begin{tabular}{lccccccc}
\hline & \multicolumn{2}{c}{} & & & & \\
& \multicolumn{2}{c}{ Species Richness } & & \multicolumn{2}{c}{ Total Cover (percent) } & \multicolumn{2}{c}{ Cyperus Cover (percent) } \\
Month & Undisturb & Disturb & \multicolumn{2}{c}{ Undisturb } & Disturb & \multicolumn{1}{c}{ Undisturb } & Disturb \\
\hline Aug. & $3.5 \pm 0.3^{\mathrm{a}}$ & $0.8 \pm 0.2^{\mathrm{b}}$ & $112.1 \pm 6.8^{\mathrm{a}}$ & $4.8 \pm 3.0^{\mathrm{b}}$ & $4.8 \pm 2.6$ & $0.0 \pm 0.0$ \\
Sept. & $3.7 \pm 0.3^{\mathrm{a}}$ & $1.8 \pm 0.4^{\mathrm{b}}$ & $79.0 \pm 8.9^{\mathrm{a}}$ & $11.1 \pm 4.5^{\mathrm{b}}$ & $15.0 \pm 5.2$ & $1.2 \pm 0.6$ \\
Oct. & $1.8 \pm 0.3^{\mathrm{a}}$ & $0.7 \pm 0.3^{\mathrm{b}}$ & $39.9 \pm 7.6$ & $7.8 \pm 4.3$ & & $12.3 \pm 4.7$ & $1.7 \pm 1.2$ \\
June & $5.4 \pm 0.3$ & $5.1 \pm 0.3$ & $101.7 \pm 11.1$ & $84.6 \pm 10.4$ & $0.0 \pm 0.0$ & $0.0 \pm 0.0$ \\
\hline
\end{tabular}




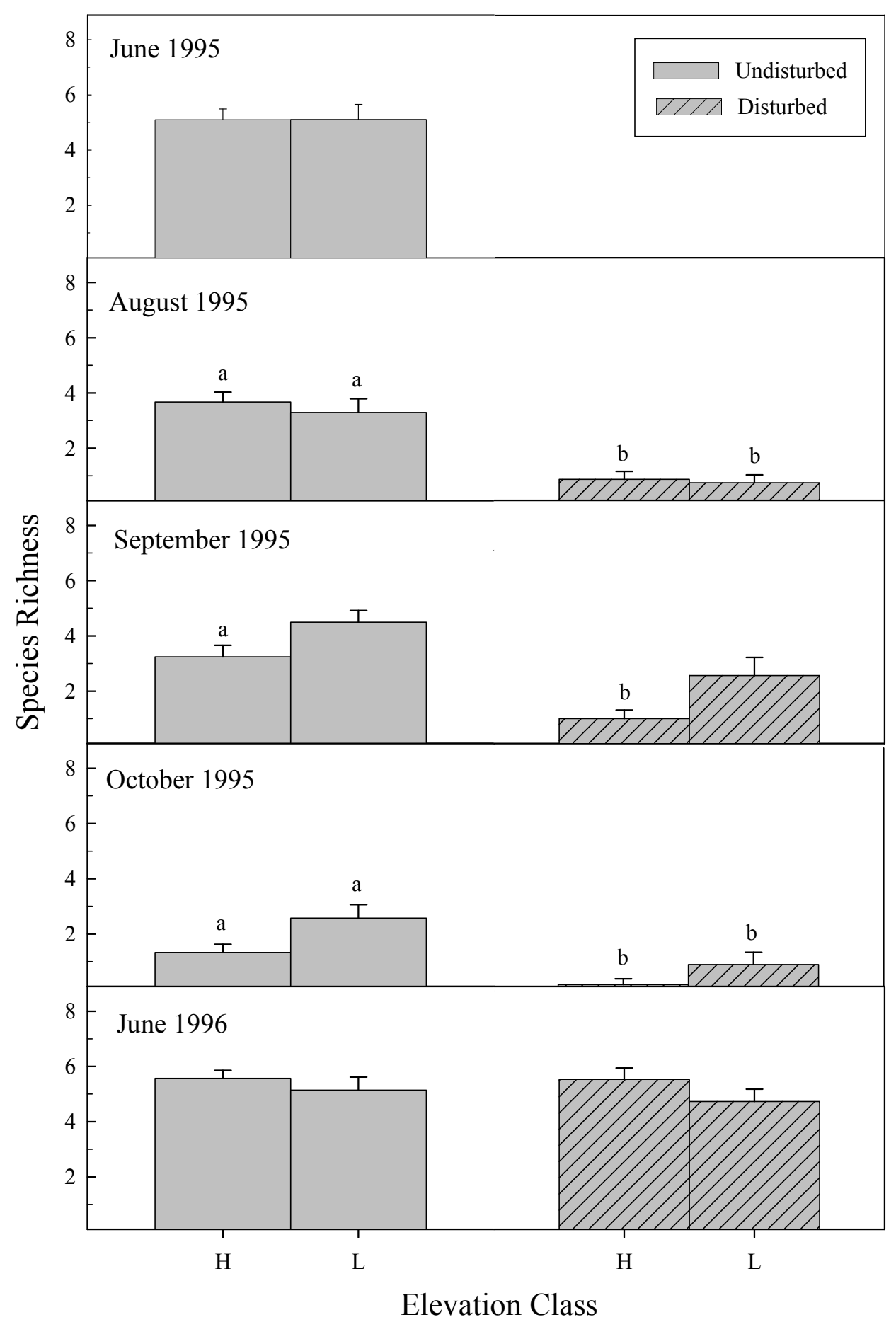

Figure 11. Species richness (mean \pm 1 SE) by elevation class on undisturbed $(n=5)$ and disturbed $(\mathrm{n}=5)$ transects at five times (disturbed transects not sampled in June 1995). Elevation classes are: $\mathrm{H}$ (high) $\geq 15 \mathrm{~cm}[0.5 \mathrm{ft}]$ and $\mathrm{L}$ (low) $<15 \mathrm{~cm}$. Significant differences between undisturbed and disturbed transects by elevation class are indicated by dissimilar letters. 


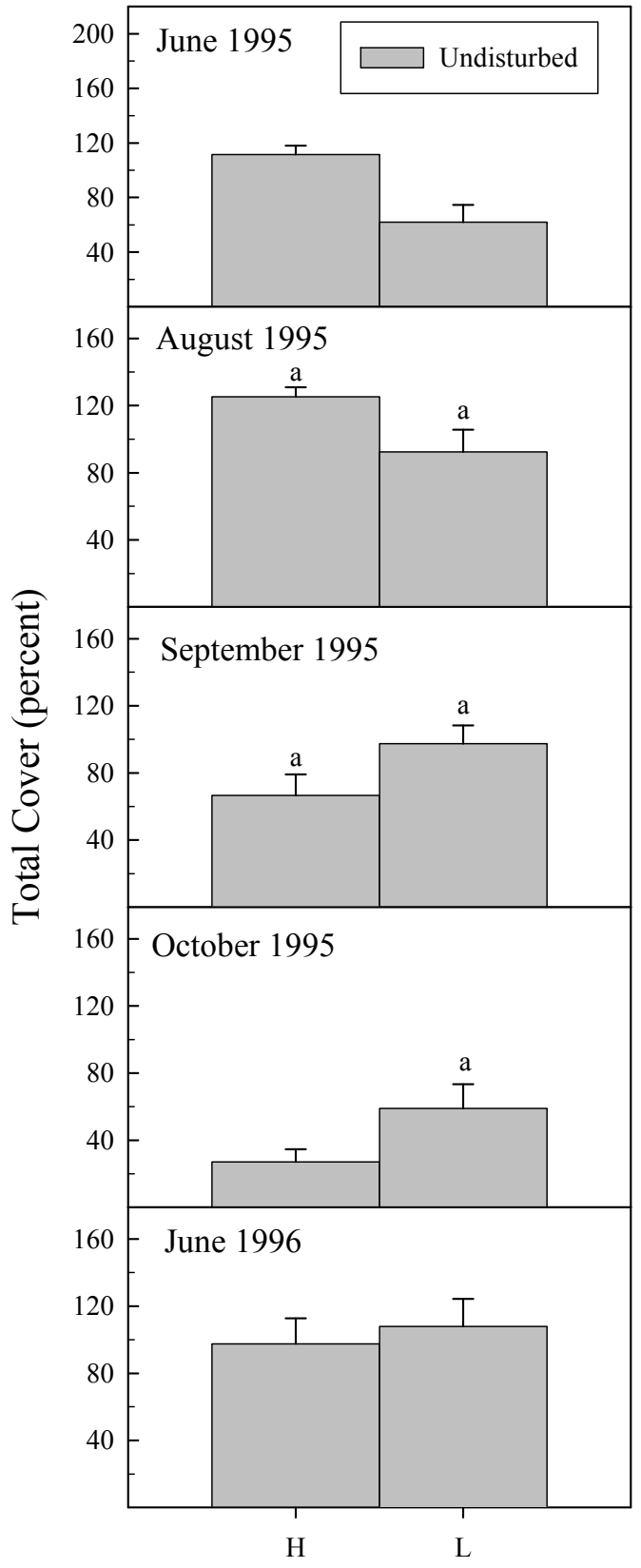

Elevation Class

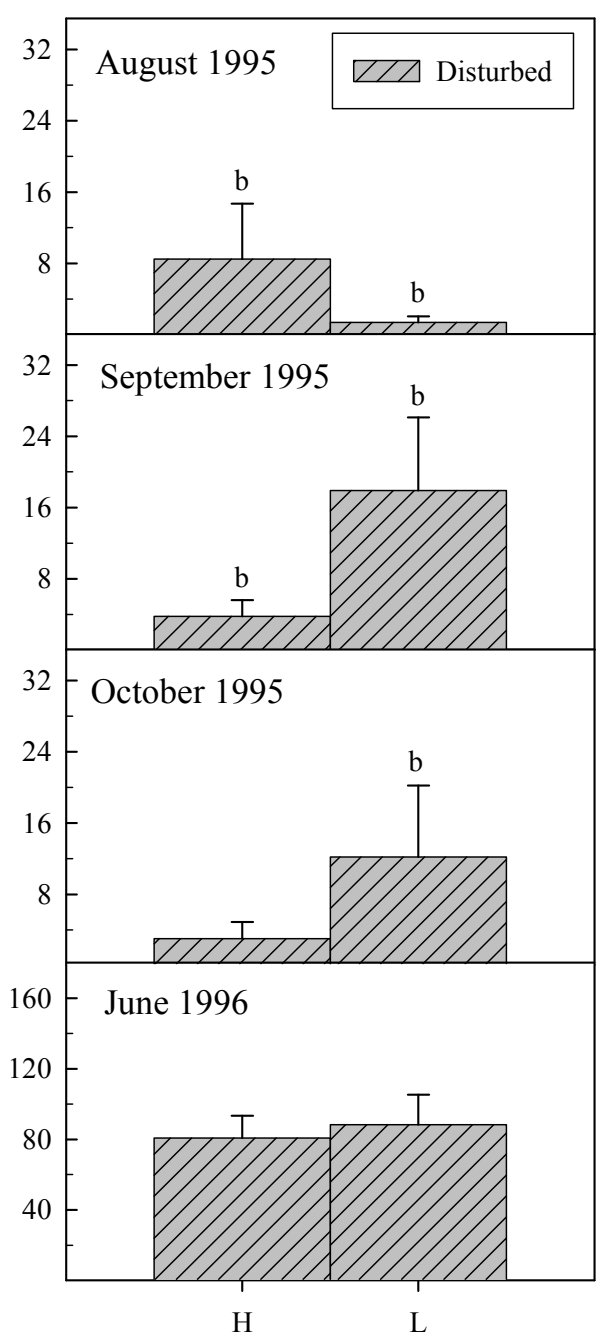

Elevation Class

Figure 12. Total vegetation cover (mean $\pm 1 \mathrm{SE}$ ) by elevation class on undisturbed $(\mathrm{n}=5)$ and disturbed $(\mathrm{n}=5)$ transects at five sampling times (disturbed transects not sampled in June 1995). Elevation classes are: $\mathrm{H}$ (high) $\geq 15 \mathrm{~cm}[0.5 \mathrm{ft}]$ and $\mathrm{L}$ (low) $<15 \mathrm{~cm}$. Note different $\mathrm{y}$-axis scales for undisturbed versus disturbed transects. Significant differences between undisturbed and disturbed transects by elevation class are indicated by dissimilar letters. 


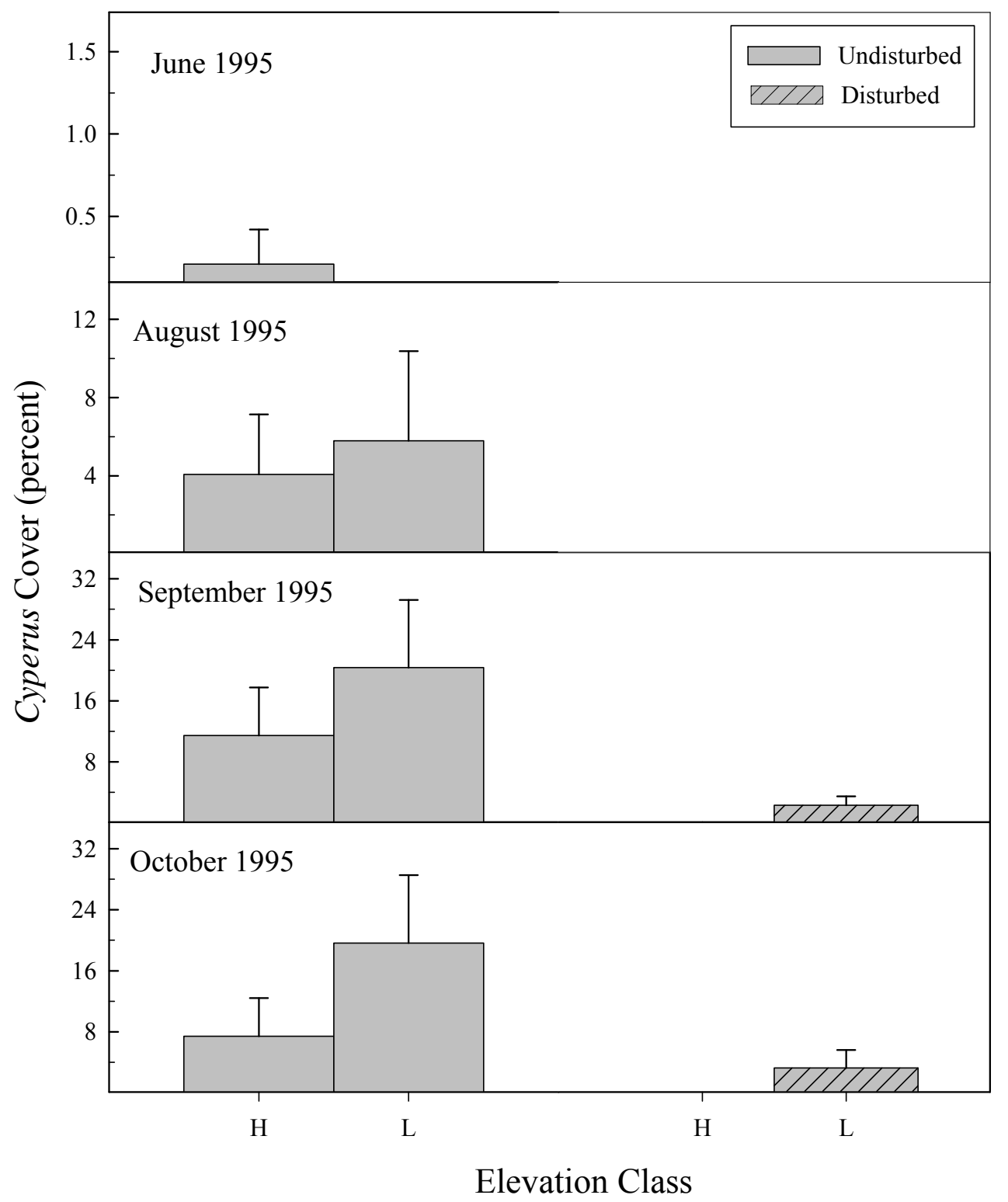

Figure 13. Cyperus cover by elevation class (mean $\pm 1 \mathrm{SE}$ ) on undisturbed $(\mathrm{n}=5)$ and disturbed $(\mathrm{n}=5)$ transects at five sampling times (disturbed transects not sampled in June 1995; no Cyperus was present on disturbed transects in August 1995). Elevation classes are: $\mathrm{H}$ (high) $\geq$ $15 \mathrm{~cm}[0.5 \mathrm{ft}]$ and $\mathrm{L}$ (low) $<15 \mathrm{~cm}$. Note variation in scale for the $\mathrm{y}$-axis. 


\section{Base Pool Stage Vegetation}

To compare plant community composition prior to and following the drawdown, 11 species with quadrat count total equal to or greater than 20 (that is, those species that appeared in 20 or more quadrats summed across all undisturbed transects) in either June 1995 or 1996 were analyzed (table 11). Categorical analysis of variance indicated significant differences in the species and time interaction $(P<0.001)$, so only the responses in terms of this interaction were examined. Pairwise comparisons identified frequency differences for nine species; only Spirodela polyrrhiza and Bacopa. egensis had similar frequencies at both times. A total of 12 species had greater than 400 percent cover at either time when summed across all undisturbed transects; the cover of six of these species varied significantly between times (table 12).

Table 11. Count of species present in 20 or more quadrats summed across all undisturbed transects in June 1995 or June 1996, plus the introduced species Bacopa egensis.

[Significant differences between times from categorical analysis of variance are indicated by dissimilar letters. Some plants were identified to genus only. Life form designations are: $\mathrm{E}=$ emergent herbaceous, $\mathrm{F}=$ floating-leaved, $\mathrm{S}=$ submersed aquatic, $\mathrm{W}=$ woody]

\begin{tabular}{lccc}
\hline & & & \\
Species & Life Form & June 1995 & June 1996 \\
\hline Azolla caroliniana & $\mathrm{F}$ & $5^{\mathrm{a}}$ & $40^{\mathrm{b}}$ \\
Bacopa egensis & $\mathrm{E}$ & 6 & 2 \\
Eleocharis microcarpa & $\mathrm{E}$ & $32^{\mathrm{a}}$ & $11^{\mathrm{b}}$ \\
Limnobium spongia & $\mathrm{F}$ & $59^{\mathrm{a}}$ & $40^{\mathrm{b}}$ \\
Ludwigia palustris & $\mathrm{E}$ & $63^{\mathrm{a}}$ & $5^{\mathrm{b}}$ \\
Ludwigia peploides & $\mathrm{E}$ & $0^{\mathrm{a}}$ & $54^{\mathrm{b}}$ \\
Najas sp. & $\mathrm{S}$ & $25^{\mathrm{a}}$ & $9^{\mathrm{b}}$ \\
Spirodela polyrrhiza & $\mathrm{F}$ & 72 & 76 \\
Utricularia gibba & $\mathrm{S}$ & $41^{\mathrm{a}}$ & $3^{\mathrm{b}}$ \\
Utricularia inflata & $\mathrm{S}$ & $8^{\mathrm{a}}$ & $50^{\mathrm{b}}$ \\
Wolffia sp. & $\mathrm{F}$ & $32^{\mathrm{a}}$ & $77^{\mathrm{b}}$ \\
\hline
\end{tabular}


Table 12. Total cover (mean $\pm 1 \mathrm{SE}, \mathrm{n}=14)$ at transects in June 1995 and 1996 of species with cover that exceeded 400 percent summed across all undisturbed transects at either time, plus the introduced species Bacopa egensis.

[Significant difference from paired t-tests are indicated by dissimilar letters. Some plants were identified to genus only. Life form designations are: $\mathrm{E}=$ emergent herbaceous, $\mathrm{F}=$ floatingleaved, $\mathrm{S}=$ submersed aquatic, $\mathrm{W}=$ woody]

\begin{tabular}{lccc}
\hline & & & \\
Species & Life Form & June 1995 & June 1996 \\
\hline Bacopa egensis & $\mathrm{E}$ & $9.7 \pm 6.1$ & $0.1 \pm 0.1$ \\
Cabomba caroliniana & $\mathrm{S}$ & $35.3 \pm 17.1$ & $11.7 \pm 10.7$ \\
Ceratophyllum demersum & $\mathrm{S}$ & $34.2 \pm 14.6$ & $2.3 \pm 1.7$ \\
Cephalanthus occidentalis & $\mathrm{W}$ & $12.1 \pm 4.7$ & $28.6 \pm 10.2$ \\
Eleocharis microcarpa & $\mathrm{E}$ & $101.2 \pm 43.4^{\mathrm{a}}$ & $19.3 \pm 14.8^{\mathrm{b}}$ \\
Limnobium spongia & $\mathrm{F}$ & $39.5 \pm 7.8$ & $30.0 \pm 17.4$ \\
Ludwigia palustris & $\mathrm{E}$ & $93.4 \pm 18.6^{\mathrm{a}}$ & $6.4 \pm 6.3^{\mathrm{b}}$ \\
Ludwigia peploides & $\mathrm{E}$ & $0.0 \pm 0.0^{\mathrm{a}}$ & $117.9 \pm 28.0^{\mathrm{b}}$ \\
Najas sp. & $\mathrm{S}$ & $95.1 \pm 28.5^{\mathrm{a}}$ & $9.0 \pm 6.4^{\mathrm{b}}$ \\
Spirodela polyrrhiza & $\mathrm{F}$ & $133.2 \pm 39.0$ & $100.5 \pm 39.4$ \\
Utricularia inflata & $\mathrm{S}$ & $18.7 \pm 13.0^{\mathrm{a}}$ & $132.0 \pm 45.1^{\mathrm{b}}$ \\
Wolffia sp. & $\mathrm{F}$ & $4.6 \pm 2.0^{\mathrm{a}}$ & $127.4 \pm 44.3^{\mathrm{b}}$ \\
\hline
\end{tabular}

Seed Bank

A total of 39 species that germinated in the two seed bank studies were identified (table 13), 17 in the June samples and 33 in the October samples; one species remained unidentified in both studies. Thirteen species that germinated from the seed bank were not present in standing vegetation in the quadrats any time during the study. The species that germinated in the most quadrats at both sampling times was Cyperus erythrorhizos (table 14). Mean species richness was $4.6 \pm 0.4(n=28)$ in June and $5.5 \pm 0.3(n=38)$ in October. Analysis of variance indicated that elevation did not have an effect on seed bank species richness at either time $(P=0.2092$ in June, $P=0.2284$ in October). Considering undisturbed transects only, a two sample t-test indicated no difference $(P=0.083)$ in mean species richness in June compared to October. Comparison of the five paired transects with soil disturbance indicated no effect $(P=0.5763)$ of the disturbance on mean species richness $(5.8 \pm 0.6$ in disturbed transects, $5.5 \pm 0.4$ in undisturbed transects; $\mathrm{n}=10$ ). Disturbance within elevation also did not affect species richness $(P=0.6213$ at low elevation, $P=0.4557$ at high elevation; $n=5)$. Comparisons between standing vegetation and germinating seeds indicated that standing vegetation richness exceeded that of the seed bank in June at low elevation only, but that seed bank richness exceeded standing vegetation at both elevations in October (table 15). 
Table 13. Plant species that germinated in soil collected at Felsenthal National Wildlife Refuge in June and October 1995 and the presence of those species in the standing vegetation at any of the five sampling events. Some plants were identified to family or genus only.

Species

Ammannia coccinea Rottb.

Bacopa egensis (Poepp.) Pennell

Bacopa rotundifolia (Michx.) Wettst.

Bidens aristosa (Michx.) Britt.

Cephalanthus occidentalis $\mathrm{L}$.

Chamaesyce humistrata (Englem.) Small

Coreopsis sp.

Cyperus erythrorhizos Muhl.

Cyperus esculentus L.

Cyperus iria L.

Cyperus sp.

Echinochloa crus-galli (L.) Beauv.

Eclipta prostata (L.) L.

Eleocharis microcarpa Torr.

Eleocharis obtusa (Willd.) J.A. Schultes

Eupatorium capillifolium (Lam.) Small

Fimbristylis autumnalis (L.) Roemer \& J.A. Shultes.

Fimbristylus miliacea (L.) Vahl

Gratiola virginiana L.

Heteranthera reniformis Ruiz \& Pavon

Leersia virginica Willd.

Lindernia dubia v. anagallidea (Michx)

Cooperrider

Lindernia dubia (L.) Pennell

Limnobium spongia (Bosc) L.C. Rich. ex Steud.

Ludwigia decurrens Walt.

Ludwigia leptocarpa (Nutt.) Hara

Ludwigia palustris (L.) Ell.

Ludwigia peploides (Kunth) Raven

Ludwigia sphaerocarpa Ell.

Panicum virgatum L.

Poaceae

Ptilimnium capillaceum (Michx) Raf.

Sagittaria latifolia Willd.

Salix nigra Marsh.
June 1995 October 1995 Standing Vegetation

$\begin{array}{ll}\mathrm{x} & \mathrm{x} \\ \mathrm{x} & \mathrm{x} \\ & \mathrm{x} \\ & \mathrm{x} \\ & \mathrm{x} \\ & \mathrm{x} \\ & \mathrm{x} \\ & \mathrm{x} \\ & \mathrm{x} \\ & \mathrm{x} \\ & \mathrm{x} \\ \mathrm{x} & \mathrm{x} \\ & \mathrm{x} \\ & \end{array}$

$\mathrm{X}$

$\mathrm{x} x$

$x$

$\mathrm{X}$

$\mathrm{x}$

$\mathrm{X}$

$\mathrm{X}$

$\mathrm{X}$

$\mathrm{X}$

$x$

$\mathrm{X}$

$\mathrm{X} \quad \mathrm{X}$

$\mathrm{x} \quad \mathrm{x}$

$\mathrm{X}-\mathrm{X}$

$\mathrm{x}-\mathrm{x}$

$\mathrm{x}$

$\mathrm{x}$

$\mathrm{x}$

$\mathrm{X}$

X

X

X

X

X

$\mathrm{X}$

X

$\mathrm{X}$

X

$\mathrm{X}$

X

X

X

X

$\mathrm{X}$

$\mathrm{X}$

$\mathrm{X}$

$\mathrm{X}$

X

X 
Table 13. Continued.

\begin{tabular}{lccc}
\hline & & & \\
Species & June 1995 & October 1995 & Standing Vegetation \\
\hline Solidago sp. & & $\mathrm{x}$ & \\
Spirodela polyrrhiza (L.) Schleid. & $\mathrm{x}$ & $\mathrm{x}$ & $\mathrm{x}$ \\
Sphenoclea zeylanica Gaertn. & & $\mathrm{x}$ & $\mathrm{x}$ \\
& & & \\
Bryophytes: & & $\mathrm{x}$ & $\mathrm{x}$ \\
Riccia sp. & $\mathrm{x}$ & $\mathrm{x}$ & $\mathrm{x}$ \\
Ricciocarpos sp. & & & \\
\hline
\end{tabular}

Table 14. The ten most-frequently germinating plant species in soil samples collected in June and October 1995 at Felsenthal National Wildlife Refuge. Total quadrat indicates the total number of quadrat samples $(n=28)$ within which the species germinated, summed across all undisturbed transects. Some plants were identified to family or genus only.

\begin{tabular}{clc}
\hline \multirow{1}{*}{ Month } & \multicolumn{1}{c}{ Species } & Total Quadrat \\
\hline June 1995 & Cyperus erythrorhizos & 23 \\
& Ludwigia peploides & 14 \\
& Lindernia dubia & 13 \\
& Poaceae & 12 \\
& Spirodela polyrrhiza & 12 \\
& Bacopa egensis & 10 \\
& Ricciocarpus sp. & 10 \\
& Riccia sp. & 7 \\
Limnobium spongia & 6 \\
& Ludwigia decurrens & 4 \\
& & 28 \\
Cyperus erythrorhizos & 14 \\
& Lindernia dubia v. anagallidea & 13 \\
Ludwigia peploides & 8 \\
Ludwigia palustris & 7 \\
Ammania coccinea & 7 \\
Ludwigia leptocarpa & 6 \\
Eleocharis obtusa & 6 \\
Poaceae & 5 \\
Eleocharis microcarpa & 4 \\
Bidens aristosa &
\end{tabular}


Table 15. Species richness (mean $\pm 1 \mathrm{SE}, \mathrm{n}=14$ ) of seed bank samples and of standing vegetation in high and low elevation quadrats; soil for seed bank studies was collected outside the quadrats where vegetation was measured. Significant differences within elevation class by month are indicated by dissimilar letters.

\begin{tabular}{lllll} 
& \multicolumn{2}{c}{ Low Elevation } & \multicolumn{2}{c}{ High Elevation } \\
Month & Vegetation & Seed Bank & Vegetation & Seed Bank \\
\hline June & $6.1 \pm 0.4^{\mathrm{a}}$ & $4.1 \pm 0.4^{\mathrm{b}}$ & $5.2 \pm 0.5$ & $5.1 \pm 0.6$ \\
October & $3.5 \pm 0.8^{\mathrm{a}}$ & $5.1 \pm 0.5^{\mathrm{b}}$ & $3.2 \pm 0.6^{\mathrm{a}}$ & $6.0 \pm 0.5^{\mathrm{b}}$ \\
\hline
\end{tabular}

\section{Soil Characteristics}

Analyses indicated the presence of predominantly mineral soils along the margin of the pool in the transects. Organic matter content in June 1995 was low, ranging from $3.57 \pm 0.48$ percent to $6.32 \pm 0.65$ percent (table 16). In June 1995, organic matter varied by transect $(P<0.001)$ and elevation class $(P<0.001)$. For transects with a significant elevation effect (transects 5,8 , $11,12,14 \mathrm{a}$, and 15a), organic matter at high elevation was greater than that at low elevation. In October, when just a single quadrat was sampled, organic matter did not differ among transects $(P=0.07)$. Soil disturbance significantly $(P=0.0397 ; \mathrm{n}=5)$ affected organic matter content, which was greater at the undisturbed ( $7.57 \pm 1.04)$ compared to the disturbed $(4.44 \pm 0.76)$ soil treatments. Examining data from quadrat 4 for undisturbed transects, organic matter content in October $(7.28 \pm 0.60)$ was greater than that in June $(4.30 \pm 0.30 ; \mathrm{n}=14 ; P=0.0014)$.

Percent carbon and nitrogen were also very low in June 1995 (table 16). At this time, the variables differed significantly by transect $(P<0.001$, both elements) and elevation $(P<0.001$, both elements). The effect of elevation was not consistent across transects. Percentage of carbon was greater at high compared to low elevation in transects $3 \mathrm{a}, 12$, and 14a, but the opposite effect was found in transects $4 \mathrm{a}$ and 9 . Percent nitrogen at high elevation was greater than that at low elevation in transects 11 and 12 but was less compared to low elevation at transects 7, 9 and 10. October samples included only one quadrat per transect, so elevation effect was not analyzed. Percent carbon and nitrogen varied among transects in October $(P<$ 0.001 , both elements). The soil disturbance treatment affected $(P=0.0342, \mathrm{n}=5)$ both elements; carbon content was higher at the undisturbed ( $3.59 \pm 0.56)$ compared to disturbed $(1.92 \pm 0.40)$ transects. Nitrogen content was also higher $(P=0.0467 ; \mathrm{n}=5)$ at the undisturbed $(0.27 \pm 0.05)$ compared to undisturbed $(0.16 \pm 0.04)$ transects. 
Table 16. Soil characteristics, expressed as percent (mean $\pm 1 \mathrm{SE}$ ), at 14 transect locations at Felsenthal National Wildlife Refuge, June 2005. The number of subsamples per transect varied from two to six.

[The abbreviation "OM" indicates organic matter]

\begin{tabular}{cccccccc}
\hline & & & & & & \\
Transect & OM & Carbon & Nitrogen & \multicolumn{1}{c}{ Sand } & \multicolumn{1}{c}{ Silt } & \multicolumn{2}{c}{ Clay } \\
\hline 1 & $4.76 \pm 0.40$ & $1.90 \pm 0.21$ & $0.18 \pm 0.01$ & $22.89 \pm 0.12$ & $12.64 \pm 0.85$ & $64.47 \pm 0.97$ \\
2a & $6.32 \pm 0.65$ & $3.08 \pm 0.19$ & $0.27 \pm 0.02$ & $2.87 \pm 0.01$ & $13.17 \pm 3.11$ & $83.96 \pm 3.10$ \\
3a & $5.34 \pm 0.41$ & $2.73 \pm 0.35$ & $0.22 \pm 0.02$ & $2.55 \pm 0.09$ & $20.31 \pm 0.47$ & $77.13 \pm 0.55$ \\
$4 \mathrm{a}$ & $5.56 \pm 0.46$ & $2.51 \pm 0.03$ & $0.22 \pm 0.02$ & $5.83 \pm 0.33$ & $16.34 \pm 3.94$ & $77.83 \pm 3.62$ \\
5 & $4.40 \pm 1.34$ & $2.20 \pm 0.75$ & $0.14 \pm 0.04$ & $53.56 \pm 5.27$ & $15.90 \pm 9.09$ & $30.53 \pm 4.60$ \\
6 & $5.50 \pm 0.32$ & $2.07 \pm 0.28$ & $0.21 \pm 0.02$ & $2.51 \pm 0.74$ & $32.41 \pm 18.99$ & $65.08 \pm 18.31$ \\
7 & $3.75 \pm 0.38$ & $1.66 \pm 0.21$ & $0.19 \pm 0.02$ & - & -- & -- \\
8 & $4.43 \pm 0.69$ & $2.00 \pm 0.42$ & $0.22 \pm 0.01$ & $1.17 \pm 0.22$ & $24.15 \pm 3.67$ & $74.67 \pm 3.86$ \\
9 & $3.57 \pm 0.48$ & $1.75 \pm 0.22$ & $0.28 \pm 0.04$ & $32.19 \pm 1.05$ & $8.25 \pm 0.61$ & $59.56 \pm 1.66$ \\
10 & $4.49 \pm 0.28$ & $2.02 \pm 0.19$ & $0.05 \pm 0.09$ & $19.51 \pm 4.68$ & $22.72 \pm 10.18$ & $57.77 \pm 14.83$ \\
11 & $4.67 \pm 1.22$ & $1.63 \pm 0.19$ & $0.32 \pm 0.17$ & $0.29 \pm 0.08$ & $41.43 \pm 14.51$ & $58.28 \pm 14.45$ \\
12 & $5.25 \pm 2.04$ & $2.79 \pm 1.16$ & $0.19 \pm 0.07$ & $32.68 \pm 1.23$ & $16.91 \pm 0.89$ & $50.41 \pm 1.98$ \\
$14 \mathrm{a}$ & $4.51 \pm 0.54$ & $2.25 \pm 0.25$ & $0.19 \pm 0.02$ & $10.56 \pm 0.82$ & $15.64 \pm 1.46$ & $73.80 \pm 2.14$ \\
$15 \mathrm{a}$ & $6.26 \pm 0.80$ & $2.36 \pm 0.40$ & $0.23 \pm 0.03$ & $9.72 \pm 0.19$ & $41.49 \pm 19.87$ & $48.78 \pm 19.81$ \\
\hline
\end{tabular}

Texture analyses indicated a predominance of clay particles in the upper 15-cm layer of soil (table 16). Because soil from a single quadrat was collected, elevation effect on soil particle size was not determined. Both percentage of sand $(P<0.001)$ and clay $(P=0.0289)$ varied by transect. Five groups were identified by sand content; excluding transects 10, 14a, and 15a, where percentage of sand was similar to that at several other transects, three distinct groups were apparent. Transect 5 had the highest sand content; transects 1, 9, and 12 were intermediate, and the remaining transects had low sand. Clay content at transects $2 \mathrm{a}, 3 \mathrm{a}, 4 \mathrm{a}, 8$, and 14a was greater than that at transect 5; percentage of clay at the remaining transects was not different from the high or low groups. Mean $(n=14)$ values in pool soils were $14.04 \pm 0.23$ for sand, $25.01 \pm 4.34$ for silt, and $60.94 \pm 4.43$ for clay.

With the exception of manganese and iron, soil nutrients (table 17) varied with either transect or elevation class (table 18). The elevation effect consisted of lower $\mathrm{Cu}$ content at high $(1.96 \pm 1.19)$ compared to low $(9.89 \pm 3.81)$ elevation at transect 12 . Mean comparisons indicated that the transects separated into five to seven groups for each element, with a great deal of overlap within the groups (table 19). 
Table 17. Concentration ( $\mathrm{mg} / \mathrm{kg}$ dry weight, mean $\pm 1 \mathrm{SE}$ ) of eight essential plant nutrients in soil collected in June 1995 at 14 transects (Trans) at Felsenthal National Wildlife Refuge.

[The number of observations per transect varied because of sample loss and instrument malfunction, ranging from one (no standard error indicated) to six; for transects combined (indicated by "all"), observations per element varied from 54 to 67 . Samples from transect 15a were lost. Data from transect 13, which was dropped from the study because of the later construction of a waterfowl capture station, are presented here]

\begin{tabular}{|c|c|c|c|c|c|c|c|c|}
\hline Trans & $\mathrm{Cu}$ & $\mathrm{Zn}$ & $\mathrm{Mn}$ & $\mathrm{Fe}$ & $\mathrm{P}$ & $\mathrm{Mg}$ & $\mathrm{Ca}$ & K \\
\hline 2 & $14.99 \pm 1.13$ & $49.40 \pm 4.28$ & $31.99 \pm$ & $2.695109 .69 \pm 403.69$ & $108.58 \pm 11.57$ & $351.15 \pm 35.65$ & $587.55 \pm 51.07$ & $246.89 \pm 27.36$ \\
\hline $4 a$ & $3.44 \pm 1.07$ & -- & $31.96 \pm 1$ & $12.082381 .28 \pm$ & $36.93 \pm 17.25$ & $193.06 \pm 30.39$ & $386.15 \pm \quad 6.95$ & $144.15 \pm 37.12$ \\
\hline $5 a$ & $4.58 \pm 1.67$ & $6.32 \pm 6.21$ & $45.84 \pm 1$ & $15.281796 .76 \pm 431.29$ & $9.96 \pm 7.99$ & $124.43 \pm 35.70$ & $136.01 \pm 24.33$ & $64.90 \pm 9.78$ \\
\hline 6 & $8.70 \pm 0.98$ & $38.77 \pm 1.45$ & $46.66 \pm$ & $7.685090 .58 \pm 80.07$ & $69.78 \pm 4.65$ & $391.39 \pm 34.42$ & $320.82 \pm 33.74$ & $211.56 \pm 15.82$ \\
\hline 9 & $6.57 \pm 0.71$ & $22.84 \pm 4.88$ & $23.86 \pm$ & $4.073108 .54 \pm 220.95$ & $34.49 \pm 4.11$ & $224.82 \pm 24.42$ & $518.69 \pm 36.45$ & $104.19 \pm 8.16$ \\
\hline 10 & $5.52 \pm 0.52$ & $13.48 \pm 1.30$ & $34.57 \pm$ & $3.293719 .48 \pm 231.22$ & $51.02 \pm 6.64$ & $225.43 \pm 25.90$ & $572.97 \pm 35.86$ & $170.68 \pm 19.88$ \\
\hline 11 & $4.62 \pm 0.49$ & $17.40 \pm 1.37$ & $34.99 \pm$ & $3.104144 .05 \pm 112.00$ & $68.65 \pm 2.60$ & $380.53 \pm 20.04$ & $465.41 \pm 37.48$ & $255.47 \pm 31.43$ \\
\hline 12 & $5.13 \pm 2.38$ & $15.70 \pm 4.38$ & $62.23 \pm 2$ & $28.113486 .06 \pm 414.94$ & $70.67 \pm 16.73$ & $165.93 \pm 25.15$ & $469.29 \pm 120.30$ & $93.60 \pm 21.74$ \\
\hline 13 & $4.31 \pm 0.62$ & $14.46 \pm 0.62$ & $20.48 \pm$ & $4.341774 .03 \pm 108.79$ & $36.61 \pm 2.36$ & $145.72 \pm 9.17$ & $384.72 \pm 15.61$ & $71.70 \pm 2.51$ \\
\hline
\end{tabular}


Table 18. Results (F value) of an analysis of variance of the effects of transect and elevation on the content of eight plant nutrients in soil at Felsenthal National Wildlife Refuge.

Significance levels are $P<0.05^{*}$ and $P<0.001^{* *}$.

\begin{tabular}{lcc} 
Element & Transect & Elevation \\
\hline $\mathrm{Cu}$ & $19.71^{* *}$ & $4.04^{*}$ \\
$\mathrm{Zn}$ & $12.64^{* *}$ & 1.81 \\
$\mathrm{Mn}$ & 2.00 & 1.74 \\
$\mathrm{Fe}$ & 1.98 & 1.23 \\
$\mathrm{P}$ & $6.29^{* *}$ & 1.02 \\
$\mathrm{Mg}$ & $11.88^{* *}$ & $2.37^{* 1}$ \\
$\mathrm{Ca}$ & $6.83^{* *}$ & 1.21 \\
$\mathrm{~K}$ & $7.61^{* *}$ & 0.94 \\
\hline
\end{tabular}

${ }^{1}$ Comparisons not significant.

Table 19. Representation of Duncan's multiple range test means comparisons by nutrient from an analysis of variance of transect effect on soil nutrient concentration. Soils were collected at Felsenthal National Wildife Refuge in June 1995. Transect did not affect soil Mn or Fe content.

[Letters indicate transects with indistinguishable means; the number of observations varied from two to six. Letters are ordered in decreasing concentration (that is, for each nutrient, group "a" has the highest concentration]

\begin{tabular}{ccccccc}
\hline Trans & $\mathrm{Cu}$ & $\mathrm{Zn}$ & $\mathrm{P}$ & $\mathrm{Ca}$ & $\mathrm{Mg}$ & $\mathrm{K}$ \\
\hline 1 & $\mathrm{a}$ & $\mathrm{ab}$ & $\mathrm{b}$ & $\mathrm{abc}$ & $\mathrm{bcd}$ & $\mathrm{abc}$ \\
2 & $\mathrm{~b}$ & $\mathrm{a}$ & $\mathrm{a}$ & $\mathrm{a}$ & $\mathrm{ab}$ & $\mathrm{ab}$ \\
3 & $\mathrm{defg}$ & $\mathrm{efg}$ & $\mathrm{bcd}$ & $\mathrm{cb}$ & ef & defg \\
4 & $\mathrm{~g}$ & $\mathrm{~g}$ & $\mathrm{cde}$ & $\mathrm{abc}$ & $\mathrm{def}$ & $\mathrm{cdef}$ \\
5 & $\mathrm{efg}$ & $\mathrm{fg}$ & $\mathrm{e}$ & $\mathrm{d}$ & $\mathrm{f}$ & $\mathrm{g}$ \\
6 & $\mathrm{c}$ & $\mathrm{ab}$ & $\mathrm{bc}$ & $\mathrm{c}$ & $\mathrm{a}$ & $\mathrm{abc}$ \\
7 & $\mathrm{cde}$ & $\mathrm{bc}$ & $\mathrm{bcd}$ & $\mathrm{ab}$ & $\mathrm{ab}$ & $\mathrm{abcde}$ \\
8 & $\mathrm{~cd}$ & $\mathrm{bc}$ & $\mathrm{bcd}$ & $\mathrm{a}$ & $\mathrm{a}$ & $\mathrm{abcd}$ \\
9 & $\mathrm{cdef}$ & $\mathrm{cde}$ & ed & $\mathrm{a}$ & $\mathrm{cde}$ & $\mathrm{defg}$ \\
10 & $\mathrm{defg}$ & efg & $\mathrm{bcd}$ & $\mathrm{a}$ & $\mathrm{cde}$ & $\mathrm{bcdef}$ \\
11 & efg & def & $\mathrm{bc}$ & $\mathrm{abc}$ & $\mathrm{a}$ & $\mathrm{ab}$ \\
12 & $\mathrm{defg}$ & def & $\mathrm{b}$ & $\mathrm{abc}$ & $\mathrm{ef}$ & $\mathrm{efg}$ \\
14 & fg & def & ed & -- & def & fg \\
\hline
\end{tabular}




\section{Discussion}

The $0.3 \mathrm{~m}(1 \mathrm{ft})$ drawdown of the pool exposed sediment that had been continuously flooded for almost 10 years. Total vegetation cover at transect locations was relatively high 4 weeks following the initiation of the drawdown (on Aug. 1, 1995) (fig. 7). Plant species dominance in the drawdown zone shifted from the submersed and floating-leaved species that were present at normal pool stage to herbaceous emergent species; a woody species, Cephalanthus occidentalis, was also dominant during the drawdown. Several of the plant species that colonized the drawdown zone are considered good seed producers and are valuable food sources for waterfowl (Fredrickson and Taylor, 1982). Desirable waterfowl food species that were relatively abundant within the drawdown zone included Cyperus erythrorhizos, Cyperus iria, Echinocloa grus-galli, Fimbristylus miliacea, Leptochloa fascicularis, Bidens aristosa, and Panicum sp. In addition to the benefits to waterfowl species, Twedt and others (1998) described the value of habitat created by reservoir drawdowns in the Mississippi Alluvial Valley to shorebirds and recommended drawing down public reservoirs from July through October to provide foraging habitat during southward migration.

The relatively abundant vegetative cover found in the drawdown zone is characteristic of vegetation succession following a decrease in water levels in wetlands (Smith and Kadlec, 1983; Welling and others, 1988). DeBerry and Perry (2005) have identified a regional drawdown flora in Virginia. The flora consists of species that form persistent seed banks in the substrate of reservoirs and characteristically produce small seeds on dense inflorescences; these species therefore are capable of producing viable seeds in large quantities. Cyperus erythrorhizos, which was dominant in the pool drawdown zone, was part of the drawdown flora described by DeBerry and Perry (2005). Seeds of Cyperus erythrorhizos have been shown to be persistent under flooded conditions and are able to germinate quickly when water recedes (Baskin and others, 1993).

The number of woody plant species, including vines, increased as a result of the pool drawdown. Woody species were absent from the list of five most frequently-occurring species in June and August 1995, but Cephalanthus occidentalis was the second most frequently-occurring species in both September and October 1995. Two woody species (Cephalanthus occidentalis and Taxodium distichum) occurred in 16 quadrats (frequency $=19.0$ percent) in June 1995. During the drawdown, woody species richness increased to three and seven in August and September, respectively, then dropped to four in October. The number of quadrats that contained woody species was 21 (frequency $=16.9$ percent), 70 (frequency $=55.6$ percent), and 49 (frequency $=39.2$ percent) in August, September, and October, respectively. Most of the woody plants identified in September and October were small seedlings of Cephalanthus occidentalis, Planera aquatica and Taxodium distichum. The drop in woody species richness and occurrence in October was probably due to grazing by small mammals, including nutria (Myocastor coypus), which were abundant in the study area. In June 1996, four woody species were found in 25 quadrats (frequency $=20.0$ percent). The frequency of Cephalanthus occidentalis dropped from a high of 38.1 in September to 16.0 in June 1996 (appendix 2), and total cover of this species dropped from a high of 731.5 percent to 438.0 percent for those two times. In comparison, cover of this species before the drawdown in June 1995 was 169.5 percent (appendix 3). Because only one measurement was made at base pool stage following the drawdown, it is not known if the increase in woody species cover persisted. It is probable, 
however, that continued flooding was stressful to young seedlings and may have led to their death. Short periods of total submergence kills seedlings of most bottomland tree species (Hosner, 1958), and even the very flood-tolerant species Taxodium distichum is only able to persist as long as some leaves remain above water during most of the growing season (Demaree, 1932). In an early study on vegetation succession in Ohio, woody plant encroachment was not a problem after seven consecutive years of July to September drawdowns in marsh habitat (Meeks, 1969). In warmer climates, however, more rapid growth of woody species may become important if the spread of these species is not desired. At Catahoula Lake in central Louisiana, annual summer drawdowns have resulted in the encroachment of Cephalanthus occidentalis and Forestiera acuminata (swamp privit) over the past several years (T. Michot, oral commun.); apparently, some seedlings were able to grow tall enough to remain above water level during normal lake levels. At Lake Chicot, also in central Louisiana, Taxodium distichum seedlings were able to establish on exposed sediments when the drawdown extended over 18 months and included two consecutive growing seasons (Keeland and Conner, 1999).

The effect of transect and elevation on vegetation response was complex. Although response varied with transect among those transects that were not subjected to soil disturbance (fig. 9), there is no consistent pattern in groupings related to direction of location along the pool margin (north, south, east, or west) or to soil characteristics. Elevation significantly affected vegetation at some transects during the drawdown, and those affects were somewhat consistent. Values reflecting vegetation response were often greater at low elevation than those at high elevation. When a response varied over time and increased at both elevations, the magnitude of the increase was greater at low compared to high elevation. When a variable decreased over time at both elevations, as did species richness from September to October on three transects, the relationship between elevations was variable. These responses may be related to species phenology and/or weather conditions during the study. The decrease in total cover on undisturbed transects in October probably reflects seasonal senescence of some species. In contrast, cover of annual Cyperus species, which can flower late in the growing season, remained fairly constant in September and October. The summer of 1995 was unusually dry in southern Arkansas (table 20), and soil moisture has been found to influence recruitment of species from the seed bank (Welling and others, 1988). It is likely that low elevation locations at the pool had sufficient moisture for seed germination and vigorous plant growth for the first several weeks of drawdown. During late summer to fall, however, the cumulative effect of the drought may have led to a dieback in vegetation. A possible explanation for the greater decrease in species richness observed at low compared to high elevation is that some species present at low elevation were more susceptible to reduced soil moisture in late summer than species at high elevations, so the decrease in richness would be more dramatic at the low elevation sites. We also noted heavy insect (beetle) herbivory in September 1995; Ludwigia peploides was the species affected to the greatest degree and was often grazed to the extent where only stems remained. 
Table 20. Precipitation by month in 1995,30 year (19611990) mean monthly precipitation, and annual precipitation in Crossett, Ark. Data for 1995 are from Felsenthal National Wildlife Refuge records and mean data are from the Crossett Water Commission, Crossett, Ark.

\begin{tabular}{lrr}
\hline & \multicolumn{2}{c}{ Precipitation $(\mathrm{cm})$} \\
\multicolumn{1}{c}{ Month } & 1995 & Mean \\
\hline January & 15.82 & 12.29 \\
February & 8.15 & 13.34 \\
March & 14.33 & 14.40 \\
April & 16.66 & 12.19 \\
May & 8.03 & 14.43 \\
June & 6.93 & 11.61 \\
July & 10.92 & 11.23 \\
August & 0.99 & 9.04 \\
September & 2.69 & 8.79 \\
October & 2.16 & 9.68 \\
November & 4.70 & 12.80 \\
December & 20.39 & 13.36 \\
Annual & 111.77 & 143.16 \\
\hline
\end{tabular}

Soil disturbance decreased species richness and total vegetation cover during the drawdown. Although soil disking and tilling are recommended as a management technique to facilitate seed germination (Fredrickson and Reid, 1988; Gray and others,1999), disking at the pool margin was logistically difficult due to the abundant woody debris. The use of a bulldozer to remove the woody debris scraped away some of the topsoil, thereby removing much of the available seed bank. It is likely that low summer rainfall levels contributed to low germination of seeds that were recruited onto disturbed transects.

Comparison of predrawdown and postdrawdown vegetation communities at base pool level indicated a significant shift in cover and frequency of some species. While submersed and floating-leaved species dominated in both June 1995 and June 1996, the frequency of the floating-leaved species Azolla caroliniana and Wolffia sp. was higher following the drawdown, while Limnobium spongia decreased (table 11). The frequency and cover of the emergent species Ludwigia palustris and Ludwigia peploides displayed opposite trends; Ludwigia palustris decreased following the drawdown while Ludwigia peploides increased (tables 11 and 12). This trend was also apparent for frequency of the submersed species Utricularia gibba and Utricularia inflata. Because of structural similarity of the species that varied between times, however, it is unlikely that the shifts affected plant community function.

Analyses of the seed bank data were problematic because different soil volumes were collected in June and October, which likely affected the total number of seeds present. Although data on species abundance (that is, cover class at two time intervals) were collected for each seed bank study, only data on species richness were analyzed; we do not believe that the sample size 
difference invalidated analyses that included this variable. Species richness per quadrat was not different between the two times, but species composition did vary. There were 22 species that germinated in October samples that were not present in June samples, and six that germinated in June but not October samples (table 13). This variation may be related to three factors: (1) species variation in timing of flowering and seed maturation, (2) inherent variability in seed longevity, and (3) the effect of prolonged flooding on seed recruitment.

Our seed bank results are consistent with those of Leeds and others (2002), who found that more species germinated in Florida Everglades soils collected in October than in soils collected in May. This variation was attributed to a July peak in seed maturity and dispersal (Leeds and others, 2002). Seed longevity varies widely among plants, ranging from less than a year to several decades (Baskin and Baskin, 1998). Many of the woody species present in bottomland hardwood forests produce short-lived seeds that are dispersed by water (Schneider and Sharitz, 1986; Middleton, 2000). Herbaceous species are well represented in the seed banks of forested systems (Leck, 1989; Middleton, 2003); in general, the mean longevity of seeds of wetland species exceeds that of woody species by about three times (Thompson and others, 1998). Results from our seed emergence studies indicate the predominance of herbaceous species in the seed bank at the pool. While seed persistence is primarily a species trait, it can be modified by environmental conditions (Fenner and Thompson, 2005). A reduction in seed species richness in wetland seed banks under prolonged flooding has been noted in several studies (for example, Keddy and Reznicek, 1982; Smith and Kadlec, 1983; Schneider and Sharitz, 1986; Poiani and Johnson, 1989). This reduction may be due to lower incorporation of seeds in standing water (Schneider and Sharitz, 1986); however, the anoxic conditions found in flooded soils reduces seed deterioration (Leck, 1989) and therefore can increase seed longevity. Because the area of our study was limited (that is, restricted to the area exposed by the $0.30-\mathrm{m}$ drawdown), it is not surprising that 13 species identified in the seed bank studies were not represented in the standing vegetation. The higher species richness in standing vegetation versus that of germinating seeds that we observed in June is consistent with a study by Bossuyt and others (2007), who examined a drained lake bed in Belgium. We can not be confident that this difference is real; as noted by Bossuyt and others (2007), it may be an artifact of the difference in sample size (that is, quadrat size was several times larger than the soil core). Higher species richness in the seed bank compared to standing vegetation, which we identified in October, is the more common relationship reported for wetlands (Smith and Kadlec, 1983; Schneider and Sharitz, 1986; Wilson and others, 1993).

The soils of the pool margin were predominantly clay with low organic matter content; some transects revealed relatively high sand content. Texture analysis results were similar to those determined for low elevation soils (19.8-20.7 m) within the greentree reservoir, where mean values were $7.33 \pm 1.49$ (mean $\pm 1 \mathrm{SE}$ ) for sand, $16.28 \pm 2.54$ for silt, and $76.41 \pm 2.98$ for clay (J. McCoy, unpub. data from 15-cm deep core samples collected July 1995; $\mathrm{n}=16$ ). Although there was no consistent trend by elevation class in June 1995, the higher organic matter content found for some transects at high compared to low elevation may be related to greater production by plants across the growing season at high elevation (that is, water less than 15 -cm deep) over the 10-year flooding period. Organic matter content at the water edge may also be influenced by the tendency for floating debris to accumulate along the shoreline. The increase in organic matter from June to October is counterintuitive. Although the aerobic conditions and higher soil temperatures during the drawdown would be expected to increase decomposition and therefore 
reduce organic matter content, the low rainfall and extremely dry conditions during the study would act to impede decomposition. In addition, difference in litter quality exists between the two times. The submersed and floating-leaved species of June are more easily consumed by microbial decomposers than the sedge and woody species that dominated in October, which have higher concentrations of recalcitrant materials such as lignin and cellulose (Lockaby and others, 1996). The lower organic matter and percentages of carbon and nitrogen content on disturbed compared to undisturbed sites was due to the fact that application of the soil disturbance removed the top several centimeters of soil. The plant nutrient concentrations in soils of the pool margin were well within the average content reported for soils worldwide and below toxic levels for plants (Market, 1992; Sparling and Lowe, 1998). It is interesting to note that transects 1 and 2 consistently had the highest nutrient concentrations, while transect 5 and often transect 4 had the lowest concentrations. All four transects are located on the western side of the pool, with transects 1 and 2 located further south towards the lock and dam. Higher nutrient concentration in the southwestern corner of the pool may be related to past land-use patterns.

\section{Conclusions and Management Implications}

The 0.3-m drawdown at the pool resulted in an increase in both emergent and woody vegetation cover within the area of exposed soil and was accompanied by an increase in cover of waterfowl food species. Total vegetation cover was generally high in undisturbed transects during the drawdown, and vegetation response was often greater at low compared to high elevation. The application of soil disturbance, which removed the upper layers of soil, decreased species richness and cover by removing the existing seed bank; these negative effects were probably intensified by the extremely dry weather conditions during the study. Seed bank studies indicated that seeds of some species, including valuable waterfowl food species, persisted during the 10-year period the pool was flooded and that the diversity of the seed bank increased during the drawdown. No distinct patterns in soil characteristics or nutrient content in the drawdown zone were identified. Pool vegetation in early summer following the drawdown was not structurally different from that prior to the drawdown, indicating no permanent impacts on vegetation. Future drawdown events are likely to follow the same trajectory, and will increase food quality and quantity for waterfowl species. Encroachment of woody vegetation into the drawdown zone is unlikely if drawdowns are scheduled on cycles that subject young seedlings to flooding stress in the subsequent growing season.

\section{Acknowledgments}

We appreciate the assistance provided by the staff at Felsenthal NWR throughout the study. Most notably, the logistical support and help provided by Robert Ellis in locating sampling sites, collecting data, and identifying plant species were essential to the completion of the study. We thank Darren Johnson for completing statistical analyses, Janelda Biagas for help with field data collection and graphics preparation, Christina Boudreaux for preparing the study area map, and Connie Herndon for editorial review. Bob Keeland provided historical data on water levels at Felsenthal lock and dam. Review comments from Bob Keeland, Rassa Dale, Beth Middleton, and Jack Waide are greatly appreciated. 


\section{References Cited}

Baskin, C.C., and Baskin, J.M., 1998, Seeds - ecology, biogeography, and evolution of dormancy and germination: San Diego, Calif., Academic Press, 666 p.

Baskin, C.C., Baskin, J.M., and Chester, E.W., 1993, Seed germination ecophysiology of four summer annual mudflat species of Cyperaceae: Aquatic Botany, v. 45, p. 41-52.

Bonham, C.D., 1989, Measurements for terrestrial vegetation: New York, John Wiley and Sons, Inc., $338 \mathrm{p}$.

Bossuyt, B., Wichelen, J. van, and Hoffman, M., 2007, Predicting future community composition from random soil seed bank sampling - evidence from a drained lake bottom: Journal of Vegetation Science, v. 18, p. 443-450.

Broadfoot, W.M., 1958, Reaction of hardwood timber to shallow-water impoundments: Stoneville, Miss., Mississippi State University Agricultural Experiment Station Information Sheet 595, 2 p.

Broadfoot, W.M., 1967, Shallow-water impoundment increases soil moisture and growth of hardwoods: Soil Science Society of America Proceedings, v. 31, p. 562-564.

Brock, S.C., Arner, D.H., and Steffen, D.E., 1994, Seed yields of four moist-soil plants on Noxubee National Wildife Refuge, in Proceedings of the Annual Conference of Southeast Association of Fish and Wildlife Agencies, v. 48: Biloxi, Miss., Southeast Association of Fish and Wildlife Agencies, p. 38-47.

DeBerry, D.A., and Perry, J.E., 2005, A drawdown flora in Virginia: Castanea, v. 70, p. 276-286.

Demaree, D., 1932, Submerging experiments with Taxodium: Ecology, v. 13, p. 258-262.

Ervin, G.N., Majure, L.C., and Bried, J.T., 2006, Influence of long-term greentree reservoir impoundment on stand structure, species composition, and hydrophytic indicators: Journal of the Torrey Botanical Society, v. 133, p. 468-481.

Fenner, M., and Thompson, K., 2005, The ecology of seeds: Cambridge, UK, Cambridge University Press, $250 \mathrm{p}$.

Fredrickson, L.H., 1991, Strategies for water level manipulations in moist-soil systems: Washington, D.C., U.S. Fish and Wildlife Service Leaflet 13.4.6, 8 p.

Fredrickson, L.H., 2005, Greentree reservoir management—implications of historic practices and contemporary considerations to maintain habitat values, in Fredrickson, L.H, King, S.L., and Kaminski, R.M., eds., Ecology and management of bottomland hardwood systems - the state of our understanding: Puxico, Mo., University of Missouri at Columbia, Gaylord Memorial Laboratory Special Publication No. 10., p. 479-486.

Fredrickson, L.H., and Batema, D.L., 1992, Greentree reservoir management handbook, Wetland Management Series No. 1: Puxico, Mo., University of Missouri at Columbia, Gaylord Memorial Laboratory, $88 \mathrm{p}$.

Fredrickson, L.H., and Reid, F.A., 1988, Preliminary considerations for manipulating vegetation: Washington, D.C., U.S. Fish and Wildlife Service Leaflet 13.4.9, 6 p.

Fredrickson, L.H., and Taylor, T.S., 1982, Management of seasonally flooded impoundments for wildlife: Washington, D.C., U.S. Fish and Wildlife Service Resource Publication 148, 29 p.

Gray, M.J., and Kaminski, R.M., 2005, Effect of continuous flooding versus periodic winter flooding on survival of oak seedlings in Mississippi greentree reservoirs, in Fredrickson, L.H., King, S.L., and Kaminski, R.M., eds., Ecology and management of bottomland hardwood systems - the state of our understanding: Puxico, Mo., University of Missouri at 
Columbia, Gaylord Memorial Laboratory Special Publication No. 10., p. 487-493.

Gray, M.J., Kaminski, R.M., Weerakkody, G., Leopold, B.D., and Jensen, K.C., 1999, Aquatic invertebrate and plant responses following mechanical manipulations of moist-soil habitat: Wildlife Society Bulletin, v. 27, p. 770-779.

Hosner, J.F., 1958, Effects of complete inundation upon seedlings of six bottomland tree species: Ecology, v. 39, p. 371-373.

Integrated Taxonomic Information System, 2007, Integrated Taxonomic Information System online database, accessed November 7, 2007, at http://www.itis.gov.

Keddy, P.A., and Reznicek, A.A., 1982, The role of seed banks in the persistence of Ontario's coastal plain flora: American Journal of Botany, v. 69, p. 13-22.

Keeland, B.D., and Conner, W.H., 1999, Natural regeneration and growth of Taxodium distichum (L.) Rich. in Lake Chicot, Louisiana, after 44 years of flooding: Wetlands, v. 19, p.149-155.

King, S.L., and Allen, J.A., 1996, Plant succession and greentree reservoir managementimplications for management and restoration of bottomland hardwood wetlands: Wetlands, $v$. 16, p. 503-511.

King, S.L., Allen, J.A., and McCoy, J.W., 1998, Long-term effects of a lock and dam and greentree reservoir management on a bottomland hardwood forest: Forest Ecology and Management, v. 112, p. 213-226.

Leck, M.A., 1989, Wetland seed banks, in Leck, M.A., Parker, V.T., and Simpson, R.L., eds., Ecology of soil seed banks: San Diego, Calif., Academic Press, Inc., p. 283-304.

Leck, M.A., and Simpson, R.L., 1995, Ten-year seed bank and vegetation dynamics of a tidal freshwater marsh: American Journal of Botany, v. 82, p. 1,547-1,557.

Leeds, J.A., Smith, S.M., and Garrett, P.B., 2002, Seedbanks and their potential role in the vegetation dynamics of a northern Everglades marsh: Florida Scientist, v. 65, p.16-34.

Lockaby, B.G., Wheat, R.S., and Clawson, R.G., 1996, Influence of hydroperiod on litter conversion to soil organic matter in a floodplain forest: Soil Science Society of America Journal, v. 60, p. 1,989-1,993.

Malecki, R.A., Lassoie, J.R., Rieger, E., and Seamans, T., 1983, Effects of long-term artificial flooding on a northern bottomland hardwood community: Forest Science, v. 29, p. 535-544.

Market, B., 1992, Presence and significance of naturally occurring chemical elements of the periodic system in the plant organism and consequences for future investigations on inorganic environmental chemistry in ecosystems: Vegetatio, v. 103, p. 1-30.

Meeks, R.L., 1969, The effect of drawdown date on wetland plant succession: Journal of Wildife Management, v. 33, 817-821.

Merz, R.W., and Brakhage, G.K., 1964, The management of pin oak in a duck shooting area: Journal of Wildlife Management, v. 28, p. 233-239.

Middleton, B., 2000, Hydrochory, seed banks, and regeneration dynamics along the landscape boundaries of a forested wetland: Plant Ecology, v. 146, p. 169-184.

Middleton, B., 2003, Soil seed banks and the potential restoration of forested wetlands after farming: Journal of Applied Ecology, v. 40, p. 1,025-1,034.

Nieuwenhuize, J., Poley-Vos, C.H., Akker, A.H. van den, and Delft, W. van, 1991, Comparison of microwave and conventional extraction techniques for the determination of metals in soil, sediment and sludge samples by atomic spectrometry: Analyst, v. 116, p. 347-351.

Poiani, K.A., and Johnson, W.C., 1988, Evaluation of the emergence method in estimating seed 
bank composition of prairie wetlands: Aquatic Botany, v. 32, p. 91-97.

Poiani, K.A., and Johnson, W.C., 1989, Effect of hydroperiod on seed-bank composition in semi permanent prairie wetlands: Canadian Journal of Botany, v. 67, p. 856-864.

Reineke, K.J., Kaminski, R.M., Moorehead, D.J., Hodges, J.D., and Nasser, J.R., 1989, Mississippi Alluvial Valley, in Smith, L.M., Pederson, R.L., and Kaminski, R.M., eds., Habitat management for migrating and wintering waterfowl in North America: Lubbock, Tex., Texas Tech University Press, p. 203-247.

Rossell, I.M., and Wells, C.L., 1999, The seed banks of a southern Appalachian fen and an adjacent degraded wetland: Wetlands, v. 19, p. 365-371.

Schneider, R.L., and Sharitz, R.R., 1986, Seed bank dynamics in a southeastern riverine swamp: American Journal of Botany, v. 73, p.1,022-1,030.

Schumacher, B.A., Neary, A.J., Palmer, C.J., Maynard, D.G., Pastorek, L., Morrison, I.K., and Marsh, M., 1995, Laboratory methods for soil and foliar analysis in long-term environmental monitoring programs: U.S. Environmental Protection Agency Report EPA/600/R-95/077, $176 \mathrm{p}$.

Smith, L.M., and Kadlec, J.A., 1983, Seed banks and their role during drawdown of a North American marsh: Journal of Applied Ecology, v. 20, p. 673-684.

Soil and Plant Analysis Council, 1992, Determination of organic matter by loss-on-ignition, in

Handbook on reference methods for soil analysis: Athens, Ga., Council on Soil Testing and Plant Analysis, Georgia University Station, p. 172-174.

Sparling, D.W., and Lowe, T.P., 1998, Metal concentration in aquatic macrophytes as influenced by soil and acidification: Water, Air and Soil Pollution, v. 108, p. 203-221.

Thompson, K., Bakker, J.P., Bekker, R.M., and Hodgson, J.G., 1998, Ecological correlates of seed persistence in soils in the north-west European flora: Journal of Ecology, v. 86, p. 163169.

Twedt, D.J., Nelms, C.O., Rettig, V.E., and Aycock, S.R., 1998, Shorebird use of managed wetlands in the Mississippi Alluvial Valley: American Midland Naturalist, v. 140, p. 140-152.

Valk, A.G. van der, and Pederson, R.L., 1989, Seed banks and the management and restoration of natural vegetation, in Leck, M.A, Parker, V.T., and Simpson, R.L., eds., Ecology of soil seed banks: San Diego, Calif., Academic Press, Inc., p. 329-346.

Welling, C.H., Pederson, R.L., and Valk, A.G. van der, 1988, Temporal patterns in recruitment from the seed bank during drawdowns in a prairie wetland: Journal of Applied Ecology, v. 25, p. $999-1,007$.

Wigley, T.B., Jr., and Filer, T.H., Jr., 1989, Characteristics of greentree reservoirs-a survey of managers: Wildlife Society Bulletin, v. 17, p. 136-142.

Wilson, C.H., Moore, D.R.J., and Keddy, P.A., 1993, Relationships of marsh seed banks to vegetation patterns along environmental gradients: Freshwater Biology, v. 29, p. 361-370.

Young, G.L., Karr, B.L., Leopold, B.D., and Hodges, J.D., 1995, Effect of greentree reservoir management on Mississippi bottomland hardwoods: Wildlife Society Bulletin, v. 23, p. 525531. 
Appendix 1. Description of 19 transects monitored at Felsenthal National Wildlife Refuge from June 1995 to June 1996, indicating quadrat distance from base marker and relative elevation. Paired transects that included a soil disturbance treatment are indicated by letters next to the transect number, $\mathrm{a}=$ undisturbed, $\mathrm{b}=$ disturbed.

[The total number of quadrats sampled for vegetation at each time were as follows: $\mathrm{n}=84$ in June 1995 (quadrat 6 was not established), $\mathrm{n}=124$ in August 1995, $\mathrm{n}=126$ in September 1995, and $\mathrm{n}=125$ in October 1995 and June 1996]

\begin{tabular}{ccccc}
\hline Transect & Quadrat & $\begin{array}{c}\text { Distance from } \\
\text { Base }(\mathrm{m})\end{array}$ & $\begin{array}{c}\text { Relative } \\
\text { Elevation }(\mathrm{ft})\end{array}$ & $\begin{array}{c}\text { Relative } \\
\text { Elevation }(\mathrm{cm})\end{array}$ \\
\hline 1 & 0 & 0.0 & 1.00 & 30.48 \\
& 1 & 7.2 & 0.86 & 26.21 \\
& 2 & 9.2 & 0.68 & 20.73 \\
& 3 & 10.3 & 0.68 & 20.73 \\
& 4 & 24.3 & 0.62 & 18.90 \\
& 5 & 23.2 & 0.27 & 8.23 \\
$2 \mathrm{a}$ & 6 & 29.4 & -0.03 & -0.91 \\
& 0 & 0.0 & 1.00 & 30.48 \\
& 1 & 12.0 & 0.70 & 21.34 \\
& 2 & 14.5 & 0.62 & 18.90 \\
& 3 & 19.1 & 0.55 & 16.76 \\
& 4 & 26.0 & 0.52 & 15.85 \\
& 5 & 38.0 & 0.26 & 7.92 \\
$\mathrm{~b}$ & 6 & 51.1 & 0.17 & 5.18 \\
& 0 & 0.0 & 1.00 & 30.48 \\
& 1 & 1.3 & 0.79 & 24.08 \\
& 2 & 3.6 & 0.63 & 19.20 \\
& 3 & 8.0 & 0.45 & 13.72 \\
& 4 & 40.5 & 0.29 & 8.84 \\
& 5 & 48.5 & 0.18 & 5.49 \\
$3 \mathrm{a}$ & 6 & 64.9 & -0.07 & -2.13 \\
& 0 & 0.0 & 1.00 & 30.48 \\
& 1 & 15.4 & 0.90 & 27.43 \\
& 2 & 27.9 & 0.81 & 24.69 \\
& 3 & 58.8 & 0.54 & 16.46 \\
& 4 & 100.8 & 0.40 & 12.19 \\
& 5 & 111.0 & 0.27 & 8.23 \\
& 6 &. & 0.18 & 5.49 \\
& & & &
\end{tabular}


Appendix 1. Continued.

\begin{tabular}{|c|c|c|c|c|}
\hline Transect & Quadrat & $\begin{array}{c}\text { Distance } \\
\text { from Base (m) }\end{array}$ & $\begin{array}{c}\text { Relative } \\
\text { Elevation (ft) }\end{array}$ & $\begin{array}{c}\text { Relative } \\
\text { Elevation }(\mathrm{cm})\end{array}$ \\
\hline \multirow[t]{6}{*}{$3 b$} & 0 & 0.0 & 1.00 & 30.48 \\
\hline & 1 & 6.5 & 0.82 & 24.99 \\
\hline & 2 & 9.7 & 0.63 & 19.20 \\
\hline & 3 & 25.6 & 0.48 & 14.63 \\
\hline & 4 & 53.5 & 0.29 & 8.84 \\
\hline & 5 & 96.0 & 0.07 & 2.13 \\
\hline \multirow[t]{7}{*}{$4 a$} & 0 & 0.0 & 1.00 & 30.48 \\
\hline & 1 & 7.9 & 0.90 & 27.43 \\
\hline & 2 & 12.2 & 0.76 & 23.16 \\
\hline & 3 & 13.6 & 0.58 & 17.68 \\
\hline & 4 & 17.6 & 0.50 & 15.24 \\
\hline & 5 & 21.7 & 0.29 & 8.84 \\
\hline & 6 & 26.9 & -0.03 & -0.91 \\
\hline \multirow[t]{6}{*}{$4 b$} & 0 & 0.0 & 1.00 & 30.48 \\
\hline & 1 & 2.0 & 0.78 & 23.77 \\
\hline & 2 & 3.1 & 0.60 & 18.29 \\
\hline & 3 & 5.5 & 0.42 & 12.80 \\
\hline & 4 & 17.5 & 0.23 & 7.01 \\
\hline & 5 & 19.6 & 0.17 & 5.18 \\
\hline \multirow[t]{7}{*}{5} & 0 & 0.0 & 1.00 & 30.48 \\
\hline & 1 & 2.1 & 0.66 & 20.12 \\
\hline & 2 & 4.3 & 0.32 & 9.75 \\
\hline & 3 & 7.1 & 0.27 & 8.23 \\
\hline & 4 & 9.0 & 0.22 & 6.71 \\
\hline & 5 & 10.8 & 0.12 & 3.66 \\
\hline & 6 & 51.5 & 0.06 & 1.83 \\
\hline \multirow[t]{6}{*}{6} & 0 & 0.0 & 1.00 & 30.48 \\
\hline & 1 & 4.0 & 0.80 & 24.38 \\
\hline & 2 & 19.4 & 0.57 & 17.37 \\
\hline & 3 & 22.7 & 0.52 & 15.85 \\
\hline & 4 & 75.4 & 0.41 & 12.50 \\
\hline & 5 & 77.9 & 0.02 & 0.61 \\
\hline \multirow[t]{6}{*}{7} & 0 & 0.0 & 1.00 & 30.48 \\
\hline & 1 & 6.7 & 0.68 & 20.73 \\
\hline & 2 & 36.4 & 0.62 & 18.90 \\
\hline & 3 & 71.7 & 0.58 & 17.68 \\
\hline & 4 & 79.7 & 0.23 & 7.01 \\
\hline & 5 & 82.3 & -0.05 & -1.52 \\
\hline
\end{tabular}


Appendix 1. Continued.

\begin{tabular}{|c|c|c|c|c|}
\hline Transect & Quadrat & $\begin{array}{c}\text { Distance } \\
\text { from Base (m) }\end{array}$ & $\begin{array}{c}\text { Relative } \\
\text { Elevation (ft) }\end{array}$ & $\begin{array}{c}\text { Relative } \\
\text { Elevation }(\mathrm{cm})\end{array}$ \\
\hline \multirow[t]{7}{*}{8} & 0 & 0.0 & 1.00 & 30.48 \\
\hline & 1 & 20.7 & 0.70 & 21.34 \\
\hline & 2 & 53.6 & 0.69 & 21.03 \\
\hline & 3 & 58.4 & 0.60 & 18.29 \\
\hline & 4 & 96.8 & 0.55 & 16.76 \\
\hline & 5 & 143.1 & 0.36 & 10.97 \\
\hline & 6 & 223.6 & 0.02 & 0.61 \\
\hline \multirow[t]{7}{*}{9} & 0 & 0.0 & 1.00 & 30.48 \\
\hline & 1 & 6.2 & 0.78 & 23.77 \\
\hline & 2 & 8.9 & 0.76 & 23.16 \\
\hline & 3 & 13.5 & 0.68 & 20.73 \\
\hline & 4 & 87.7 & 0.57 & 17.37 \\
\hline & 5 & 99.0 & 0.29 & 8.84 \\
\hline & 6 & 134.4 & -0.11 & -3.35 \\
\hline \multirow[t]{7}{*}{10} & 0 & 0.0 & 1.00 & 30.48 \\
\hline & 1 & 6.0 & 0.75 & 22.86 \\
\hline & 2 & 9.2 & 0.62 & 18.90 \\
\hline & 3 & 13.7 & 0.49 & 14.94 \\
\hline & 4 & 15.2 & 0.30 & 9.14 \\
\hline & 5 & 17.5 & 0.09 & 2.74 \\
\hline & 6 & 22.0 & -0.03 & -0.91 \\
\hline \multirow[t]{7}{*}{11} & 0 & 0.0 & 1.00 & 30.48 \\
\hline & 1 & 1.9 & 0.90 & 27.43 \\
\hline & 2 & 4.3 & 0.86 & 26.21 \\
\hline & 3 & 14.6 & 0.52 & 15.85 \\
\hline & 4 & 18.7 & 0.34 & 10.36 \\
\hline & 5 & 21.1 & 0.30 & 9.14 \\
\hline & 6 & 36.7 & -0.18 & -5.49 \\
\hline \multirow[t]{6}{*}{12} & 0 & 0.0 & 1.00 & 30.48 \\
\hline & 1 & 1.9 & 0.94 & 28.65 \\
\hline & 2 & 2.5 & 0.87 & 26.52 \\
\hline & 3 & 5.3 & 0.84 & 25.60 \\
\hline & 4 & 17.0 & 0.44 & 13.41 \\
\hline & 5 & 19.4 & 0.07 & 2.13 \\
\hline
\end{tabular}


Appendix 1. Continued.

\begin{tabular}{ccccc}
\hline Transect & Quadrat & $\begin{array}{c}\text { Distance } \\
\text { from Base }(\mathrm{m})\end{array}$ & $\begin{array}{c}\text { Relative } \\
\text { Elevation }(\mathrm{ft})\end{array}$ & $\begin{array}{c}\text { Relative } \\
\text { Elevation }(\mathrm{cm})\end{array}$ \\
\hline 14a & 0 & 0.0 & 1.00 & 30.48 \\
& 1 & 3.7 & 0.90 & 27.43 \\
& 2 & 13.6 & 0.63 & 19.20 \\
& 3 & 15.5 & 0.68 & 20.73 \\
& 4 & 18.3 & 0.49 & 14.94 \\
& 5 & 45.0 & 0.38 & 11.58 \\
$14 \mathrm{~b}$ & 6 & 69.0 & -0.02 & -0.61 \\
& 0 & 0.0 & 1.00 & 30.48 \\
& 1 & 3.0 & 0.72 & 21.95 \\
& 2 & 5.7 & 0.59 & 17.98 \\
& 3 & 18.2 & 0.45 & 13.72 \\
& 4 & 28.1 & 0.24 & 7.32 \\
& 5 & 46.4 & 0.25 & 7.62 \\
& 0 & 0.0 & 1.00 & 30.48 \\
& 1 & 10.9 & 0.72 & 21.95 \\
& 2 & 13.3 & 0.66 & 20.12 \\
& 3 & 15.5 & 0.60 & 18.29 \\
& 4 & 17.0 & 0.40 & 12.19 \\
& 5 & 24.0 & 0.13 & 3.96 \\
& 6 & 32.0 & -0.12 & -3.66 \\
& 0 & 0.0 & 1.00 & 30.48 \\
& 1 & 3.2 & 0.85 & 25.91 \\
& 2 & 8.5 & 0.63 & 19.20 \\
& 3 & 18.5 & 0.45 & 13.72 \\
& 4 & 22.5 & 0.20 & 6.10 \\
& 5 & 29.6 & 0.06 & 1.83 \\
\hline
\end{tabular}


Appendix 2. Frequency of occurrence (percentage) of plant species at five sampling times at Felsenthal National Wildlife Refuge. See table 3 of the report for species codes.

\begin{tabular}{|c|c|c|c|c|c|}
\hline Species & June 1995 & Aug. 1995 & $\frac{\text { Month }}{\text { Sept. } 1995}$ & Oct. 1995 & June 1996 \\
\hline Amco & 1.2 & 5.6 & 7.1 & 4.0 & 0.0 \\
\hline Azca & 6.0 & 0.0 & 0.8 & 0.8 & 41.6 \\
\hline Baeg & 7.1 & 2.4 & 5.6 & 1.6 & 1.6 \\
\hline Baro & 4.8 & 1.6 & 0.0 & 0.0 & 0.8 \\
\hline Biar & 10.7 & 17.7 & 22.2 & 13.6 & 12.8 \\
\hline Brov & 0.0 & 0.0 & 3.2 & 3.2 & 0.8 \\
\hline Caca & 17.9 & 0.0 & 0.8 & 0.0 & 10.4 \\
\hline Casp & 0.0 & 0.8 & 0.0 & 0.8 & 0.0 \\
\hline Cede & 21.4 & 0.8 & 2.4 & 0.0 & 4.8 \\
\hline Ceoc & 17.9 & 12.9 & 38.1 & 28.8 & 16.0 \\
\hline $\mathrm{Cy}$ & 4.8 & 20.2 & 13.5 & 0.0 & 0.0 \\
\hline Cyer & 0.0 & 0.8 & 1.6 & 44.0 & 0.0 \\
\hline Cyir & 0.0 & 3.2 & 35.7 & 1.6 & 0.0 \\
\hline Dite & 0.0 & 0.8 & 3.2 & 2.4 & 0.0 \\
\hline Divi & 0.0 & 0.0 & 1.6 & 0.0 & 0.0 \\
\hline Ecco & 9.5 & 8.9 & 7.9 & 5.6 & 8.0 \\
\hline Eccr & 0.0 & 0.8 & 10.3 & 4.0 & 0.0 \\
\hline Ecpr & 0.0 & 0.0 & 16.7 & 10.4 & 0.0 \\
\hline Elmi & 38.1 & 42.7 & 19.0 & 13.6 & 11.2 \\
\hline Elob & 1.2 & 2.4 & 2.4 & 1.6 & 0.0 \\
\hline Fimi & 0.0 & 1.6 & 13.5 & 4.8 & 0.0 \\
\hline Glaq & 0.0 & 0.0 & 0.8 & 0.0 & 0.0 \\
\hline Here & 3.6 & 10.5 & 1.6 & 0.8 & 0.8 \\
\hline Hisp & 0.0 & 0.0 & 0.8 & 1.6 & 0.0 \\
\hline Hyqu & 0.0 & 3.2 & 1.6 & 3.2 & 4.0 \\
\hline Ipsp & 0.0 & 1.6 & 0.0 & 0.0 & 0.0 \\
\hline Jusp & 0.0 & 0.0 & 0.8 & 0.0 & 0.0 \\
\hline Lefa & 0.0 & 0.0 & 0.8 & 7.2 & 0.0 \\
\hline Leor & 1.2 & 5.6 & 1.6 & 0.8 & 1.6 \\
\hline Lidu & 0.0 & 2.4 & 7.1 & 3.2 & 0.0 \\
\hline Lisp & 70.2 & 14.5 & 12.7 & 8.0 & 41.6 \\
\hline Lude & 6.0 & 3.2 & 7.1 & 4.0 & 0.0 \\
\hline Lule & 0.0 & 0.0 & 7.9 & 0.0 & 0.0 \\
\hline
\end{tabular}


Appendix 2. Continued.

\begin{tabular}{|c|c|c|c|c|c|}
\hline Species & June 1995 & Aug. 1995 & $\frac{\text { Month }}{\text { Sept. } 1995}$ & Oct. 1995 & June 1996 \\
\hline Lupa & 75.0 & 19.4 & 2.4 & 0.0 & 19.6 \\
\hline Lupe & 0.0 & 54.0 & 53.2 & 4.0 & 57.6 \\
\hline Lusp & 1.2 & 1.6 & 2.4 & 0.0 & 0.0 \\
\hline Luur & 0.0 & 0.8 & 0.0 & 0.0 & 0.0 \\
\hline Misc & 0.0 & 0.8 & 3.2 & 4.0 & 0.0 \\
\hline Mist & 0.0 & 0.0 & 1.6 & 0.8 & 0.0 \\
\hline Mysp & 1.2 & 0.8 & 0.0 & 0.8 & 0.8 \\
\hline Nasp & 29.8 & 0.0 & 0.0 & 0.0 & 18.4 \\
\hline Pasp & 3.6 & 0.0 & 2.4 & 0.0 & 0.0 \\
\hline Plaq & 0.0 & 3.2 & 4.8 & 5.6 & 1.6 \\
\hline Plfo & 0.0 & 0.0 & 1.6 & 1.6 & 0.0 \\
\hline Po & 0.0 & 0.8 & 1.6 & 0.0 & 2.4 \\
\hline Poan & 0.0 & 0.0 & 1.6 & 0.0 & 0.0 \\
\hline Poau & 0.0 & 0.0 & 0.0 & 3.2 & 0.0 \\
\hline Posp & 15.5 & 0.0 & 0.0 & 0.0 & 18.4 \\
\hline Rhsp & 0.0 & 0.8 & 0.0 & 0.0 & 0.0 \\
\hline Rici & 2.4 & 0.0 & 1.6 & 1.6 & 1.6 \\
\hline Rico & 0.0 & 0.0 & 0.0 & 3.2 & 0.8 \\
\hline Sagr & 2.2 & 0.0 & 0.0 & 0.0 & 0.0 \\
\hline Sala & 10.7 & 12.9 & 11.1 & 4.8 & 1.6 \\
\hline Sasp & 0.0 & 0.0 & 0.0 & 0.0 & 0.8 \\
\hline Seex & 0.0 & 3.2 & 5.6 & 1.6 & 0.8 \\
\hline Sppo & 85.7 & 19.4 & 11.9 & 4.0 & 87.2 \\
\hline Spze & 4.8 & 10.5 & 15.1 & 3.2 & 0.8 \\
\hline Tadi & 1.2 & 0.8 & 6.3 & 1.6 & 1.6 \\
\hline Trwa & 17.9 & 13.7 & 16.7 & 16.8 & 12.8 \\
\hline Uk & 1.2 & 0.8 & 6.6 & 0.0 & 14.4 \\
\hline Utgi & 48.8 & 3.2 & 3.2 & 2.4 & 7.2 \\
\hline Utin & 9.5 & 0.0 & 0.0 & 0.0 & 60.8 \\
\hline Viro & 0.0 & 0.0 & 0.8 & 0.0 & 0.0 \\
\hline Wosp & 38.0 & 1.6 & 4.8 & 1.6 & 89.6 \\
\hline Xast & 0.0 & 0.0 & 0.8 & 0.8 & 0.0 \\
\hline
\end{tabular}


Appendix 3. Plant species total cover summed over transects at five sampling times at Felsenthal National Wildlife Refuge. See table 3 of the report for species codes.

\begin{tabular}{|c|c|c|c|c|c|}
\hline Species & June 1995 & Aug. 1995 & $\stackrel{\text { Month }}{\text { Sept. } 1995}$ & Oct. 1995 & June 1996 \\
\hline Amco & 0.5 & 74.5 & 24.5 & 14.5 & 0.0 \\
\hline Azca & 10.5 & 0.0 & 0.5 & 0.5 & 209.5 \\
\hline Baeg & 136.0 & 5.5 & 80.0 & 9.0 & 1.0 \\
\hline Baro & 14.0 & 5.0 & 0.0 & 0.0 & 4.5 \\
\hline Biar & 12.5 & 63.0 & 254.0 & 202.5 & 8.0 \\
\hline Brov & 0.0 & 0.0 & 2.0 & 23.5 & 0.5 \\
\hline Caca & 494.0 & 0.0 & 0.5 & 0.0 & 308.5 \\
\hline Casp & 0.0 & 0.5 & 0.0 & 0.5 & 0.0 \\
\hline Cede & 479.0 & 4.5 & 1.5 & 0.0 & 120.5 \\
\hline Ceoc & 169.5 & 253.0 & 731.5 & 663.0 & 438.0 \\
\hline $\mathrm{Cy}$ & 14.0 & 110.5 & 116.5 & 0.0 & 0.0 \\
\hline Cyer & 0.0 & 63.0 & 67.5 & $2,172.5$ & 0.0 \\
\hline Cyir & 0.0 & 103.5 & $2,185.0$ & 18.5 & 0.0 \\
\hline Dite & 0.0 & 0.5 & 18.0 & 5.5 & 0.0 \\
\hline Divi & 0.0 & 0.0 & 5.0 & 0.0 & 0.0 \\
\hline Ecco & 92.0 & 144.5 & 135.0 & 27.5 & 217.5 \\
\hline Eccr & 0.0 & 18.0 & 233.5 & 119.5 & 0.0 \\
\hline Ecpr & 0.0 & 0.0 & 72.0 & 50.5 & 0.0 \\
\hline Elmi & $1,417.0$ & $2,017.0$ & 779.0 & 642.5 & 275.0 \\
\hline Elob & 88.0 & 5.5 & 9.0 & 22.5 & 0.0 \\
\hline Fimi & 0.0 & 88.5 & 237.0 & 250.5 & 0.0 \\
\hline Glaq & 0.0 & 0.0 & 0.5 & 0.0 & 0.0 \\
\hline Here & 23.0 & 219.0 & 1.0 & 18.0 & 4.5 \\
\hline Hisp & 0.0 & 0.0 & 4.5 & 5.0 & 0.0 \\
\hline Hyqu & 0.0 & 37.0 & 151.0 & 111.0 & 116.5 \\
\hline Ipsp & 0.0 & 5.0 & 0.0 & 0.0 & 0.0 \\
\hline Jusp & 0.0 & 0.0 & 0.5 & 0.0 & 0.0 \\
\hline Lefa & 0.0 & 0.0 & 4.5 & 248.5 & 0.0 \\
\hline Leor & 4.5 & 15.5 & 1.0 & 4.5 & 5.0 \\
\hline Lidu & 0.0 & 1.5 & 34.0 & 18.0 & 0.0 \\
\hline Lisp & 553.0 & 73.5 & 252.0 & 142.5 & 453.5 \\
\hline Lude & 24.0 & 18.0 & 55.5 & 55.0 & 0.0 \\
\hline Lule & 0.0 & 0.0 & 125.5 & 0.0 & 0.0 \\
\hline
\end{tabular}


Appendix 3. Continued.

\begin{tabular}{|c|c|c|c|c|c|}
\hline Species & June 1995 & Aug. 1995 & $\frac{\text { Month }}{\text { Sept. } 1995}$ & Oct. 1995 & June 1996 \\
\hline Lupa & $1,307.0$ & 796.5 & 23.0 & 0.0 & 123.0 \\
\hline Lupe & 0.0 & $3,324.0$ & $2,337.0$ & 18.5 & $1,712.5$ \\
\hline Lusp & 4.4 & 5.0 & 1.5 & 0.0 & 0.0 \\
\hline Luur & 0.0 & 38.0 & 0.0 & 0.0 & 0.0 \\
\hline Misc & 0.0 & 0.5 & 6.0 & 22.5 & 0.0 \\
\hline Mist & 0.0 & 0.0 & 9.0 & 0.5 & 0.0 \\
\hline Mysp & 0.5 & 4.5 & 0.0 & 4.5 & 18.0 \\
\hline Nasp & $1,331.0$ & 0.0 & 0.0 & 0.0 & 515.5 \\
\hline Pasp & 5.5 & 0.0 & 5.5 & 0.0 & 0.0 \\
\hline Plaq & 0.0 & 14.0 & 19.0 & 15.5 & 5.0 \\
\hline Plfo & 0.0 & 0.0 & 5.0 & 9.0 & 0.0 \\
\hline Po & 0.0 & 0.5 & 5.0 & 0.0 & 1.5 \\
\hline Poan & 0.0 & 0.0 & 1.0 & 0.0 & 0.0 \\
\hline Poau & 0.0 & 0.0 & 0.0 & 14.0 & 0.0 \\
\hline Posp & 107.0 & 0.0 & 0.0 & 0.0 & 588.5 \\
\hline Rhsp & 0.0 & 4.5 & 0.0 & 0.0 & 0.0 \\
\hline Rici & 1.0 & 0.0 & 1.0 & 1.0 & 1.0 \\
\hline Rico & 0.0 & 0.0 & 0.0 & 6.0 & 0.5 \\
\hline Sagr & 1.0 & 0.0 & 0.0 & 0.0 & 0.0 \\
\hline Sala & 217.0 & 469.0 & 304.0 & 23.0 & 42.5 \\
\hline Sasp & 0.0 & 0.0 & 0.0 & 0.0 & 0.5 \\
\hline Seex & 0.0 & 6.0 & 166.5 & 9.0 & 0.5 \\
\hline Sppo & $1,864.5$ & 278.0 & 179.5 & 28.0 & $2,185.5$ \\
\hline Spze & 10.0 & 228.5 & 441.0 & 19.5 & 0.5 \\
\hline Tadi & 0.5 & 0.5 & 16.0 & 5.0 & 1.0 \\
\hline Trwa & 51.5 & 105.0 & 237.0 & 250.0 & 41.5 \\
\hline Uk & 0.5 & 0.5 & 4.0 & 0.0 & 9.0 \\
\hline Utgi & 178.5 & 2.0 & 39.5 & 72.0 & 30.0 \\
\hline Utin & 262.0 & 0.0 & 0.0 & 0.0 & $2,930.0$ \\
\hline Viro & 0.0 & 0.0 & 0.5 & 0.0 & 0.0 \\
\hline Wosp & 64.0 & 5.0 & 215.5 & 1.0 & $2,675.0$ \\
\hline Xast & 0.0 & 0.0 & 4.5 & 4.5 & 0.0 \\
\hline
\end{tabular}


